Józef Chojnacki (iD) https://orcid.org/0000-0003-3530-7742 Akademia Humanistyczno-Ekonomiczna w Łodzi e-mail: j.chojnacki10@wp.pl

\title{
Zabytki rękopiśmienne z Pyzdr z drugiej połowy XVI wieku. Uwarunkowania historyczne. Właściwości językowe w kontekście tendencji rozwojowych i unifikacyjnych języka narodowego
}

Szanownemu Panu Michałowi Czerniakowi Kustoszowi Muzeum Okręgowego w Pyzdrach składam serdeczne podziękowanie za udostępnienie zbiorów

\section{Streszczenie}

W Muzeum Regionalnym w Pyzdrach (miasteczko nad Wartą) znajdują się szesnastowieczne rękopiśmienne zabytki językowe (języka polskiego). Zabytki zawierają treść przywilejów mieszczańskich z Pyzdr (drugiej połowy XVI wieku). W artykule zamieszczono krótki opis przywilejów dotyczących miasta królewskiego Pyzdr. Dokonano analizy zabytków w kontekście udokumentowanych zjawisk językowych Wielkopolski (ze szczególnym uwzględnieniem cech regionalnych).

Słowa kluczowe: przywileje mieszczańskie, kształtowanie się języka ogólnopolskiego, regionalne archaizmy językowe, kontynuacje niektórych szesnastowiecznych regionalizmów we współczesnych gwarach 


\section{Objaśnienia skrótów}

\section{Skróty cytowanych publikacji}

GH I - Z. Klemensiewicz, T. Lehr-Spławiński, S. Urbańczyk (1956), Gramatyka historyczna języka polskiego, Warszawa.

GH II - S. Rospond (1973), Gramatyka historyczna języka polskiego, Warszawa.

ReczekPSdp. - S. Reczek (1968), Podręczny słownik dawnej polszczyzny, WrocławWarszawa-Kraków.

Rymut I - K. Rymut (1999), Nazwiska Polaków. Słownik historyczno-etymologiczny, t. I, Kraków.

Rymut II - K. Rymut (2001), Nazwiska Polaków. Słownik historyczno-etymologiczny, t. II, Kraków.

SJPD III - W. Doroszewski (red.) (1964), Słownik języka polskiego, t. III, Warszawa. SJPD V - W. Doroszewski (red.) (1963), Stownik języka polskiego, t. V, Warszawa. SławskiSEJP II - F. Sławski (1958-1965), Słownik etymologiczny języka polskiego, t. II, Kraków.

SławskiSEJP III - F. Sławski (1966-1969), Słownik etymologiczny języka polskiego, t. III, Kraków.

Cieślikowa i in., 2000 - A. Cieślikowa, J. Szymowa, K. Rymut (oprac.) (2000), Stownik etymologiczno-motywacyjny staropolskich nazw osobowych. Czesść 1. Odapelatywne nazwy osobowe, Kraków.

Malec, 1995 - M. Malec (oprac.) (1995), Słownik etymologiczno-motywacyjny staropolskich nazw osobowych. Część 2. Nazwy osobowe pochodzenia chrześcijańskiego, Kraków. Sstp. III, z. 6(19) - S. Urbańczyk, Z. Klemensiewicz, J. Safarewicz, W. Kuraszkiewicz, W. Taszycki (red.) (1960-1962), Słownik staropolski, t. III, z. 6(19), Wrocław-Warszawa-Kraków.

Sstp. IV, z. 4(23) - S. Urbańczyk, Z. Klemensiewicz, J. Safarewicz, W. Kuraszkiewicz, W. Taszycki (red.) (1964), Słownik staropolski, z. 4(23), Wrocław-Warszawa-Kraków. Sstp. V, z. 7(31) - S. Urbańczyk, Z. Klemensiewicz, J. Safarewicz, W. Kuraszkiewicz, W. Taszycki (red.) (1968), Słownik staropolski, t. V, z. 7(31), Wrocław-Warszawa-Kraków. Sstp. V, z. 8(32) - S. Urbańczyk, Z. Klemensiewicz, J. Safarewicz, W. Kuraszkiewicz, E. Ostrowska, W. Taszycki (red.) (1969), Słownik staropolski, t. V, z. 8(32), WrocławWarszawa-Kraków.

Sstp. VI, z. 7(40) - S. Urbańczyk, Z. Klemensiewicz, J. Safarewicz, W. Kuraszkiewicz, E. Ostrowska, W. Taszycki (red.) (1973), Stownik staropolski, t. VI, z. 7(40), WrocławWarszawa-Kraków-Gdańsk.

Sstp. VII, z. 3(43) - S. Urbańczyk, Z. Klemensiewicz, J. Safarewicz, W. Kuraszkiewicz, E. Ostrowska, W. Taszycki (red.) (1974), Słownik staropolski, t. VII, z. 3(43), WrocławWarszawa-Kraków-Gdańsk.

Sstp. X, z. 4(64) - S. Urbańczyk, J. Safarewicz, W. Kuraszkiewicz (red.) (1991), Słownik staropolski, t. X, z. 4(64), Kraków. 
SW I - J. Karłowicz, A. Kryński, W. Niedźwiedzki (1900), Słownik języka polskiego, t. I, Warszawa.

SW II - J. Karłowicz, A. Kryński, W. Niedźwiedzki (1902), Słownik języka polskiego, t. II, Warszawa.

SW IV - J. Karłowicz, A. Kryński, W. Niedźwiedzki (1908), Słownik języka polskiego, t. IV, Warszawa.

SWO - J. Tokarski (red. nauk.) (1974), Słownik wyrazów obcych, Warszawa.

Pozostałe zastosowane w tekście skróty mają rozwiązanie w odnośnych pozycjach Spisu cytowanych publikacji.

\section{Skróty określeń, terminów gramatycznych}

B. - biernik

C. - celownik

D. - dopełniacz

fem. - femininum

gw. - gwarowy

instr. - instrumentalis

1. mn. - liczba mnoga

1. p. - liczba pojedyncza

M. - mianownik

masc. - maskulinum

Msc. - miejscownik

N. - narzędnik

neutr. - neutrum

niem. - niemiecki

poł. - połowa

por. - porównaj

przym. - przymiotnik

psł. - prasłowiański

r. m. - rodzaj męski

r. ż. - rodzaj żeński

r. n. - rodzaj nijaki

ros. - rosyjski

sing. - singularis

stpol. - staropolski

\section{Wstęp}

Pyzdry to niewielkie miasteczko (około 3 tys. mieszkańców) w powiecie wrzesińskim. Położone są na prawym brzegu Warty, około $3 \mathrm{~km}$ od ujścia Prosny do tej rzeki. Brzeg

\footnotetext{
1 Por. Chojnacki, 1994: 183-184.
} 
Warty jest w tym miejscu wysoki, dlatego z daleka widać piękne budynki - dawny klasztor franciszkański (wraz z kościołem) i potężną bryłę fary. Od północnego wschodu dochodzi do Pyzdr droga, biegnąca wzdłuż obszernego rozlewiska warcianego, w którym można dostrzec równoległe do koryta rzeki starorzecza.

W latach trzydziestych XIII wieku istniał tu gród pyzdrski. Gród powstał w okresie nasilenia walk międzydzielnicowych (rozbicie dzielnicowe). Pyzdry należały w tym czasie do dóbr książęcych. Można z tym faktem łączyć nazwiska panujących w Wielkopolsce książąt, takich jak Mieszko Stary, Władysław Laskonogi, Władysław Odonic, książę śląski Henryk Brodaty (Wędzki, 2007: 61-63).

Pierwsza wzmianka o Pyzdrach w źródłach pochodzi z roku 1234. Doszło wówczas do opanowania przez księcia śląskiego Henryka Brodatego południowej i zachodniej części Wielkopolski - w zapisie o tym wydarzeniu wymieniono nazwę Pyzdry. Dokładnej daty lokacji miejskiej Pyzdr nie ustalono. Mogła ona nastąpić między 20 kwietnia 1253 roku a 29 listopada 1257 roku. Był to okres nasilenia się przeprowadzanej reformy miejskiej w Wielkopolsce. „Najstarszy ślad funkcjonowania Pyzdr jako miasta lokacyjnego odnajdujemy w wystawionym 29 XI 1257 r. w Poznaniu dokumencie księcia wielkopolskiego Bolesława Pobożnego. Akt ten, przeznaczony dla klasztoru cystersów w Obrze, nie dotyczył bezpośrednio Pyzdr, wśród obecnych przy jego wydaniu i wymienionych w tekście świadków znalazł się jednak wójt pyzdrski” (Czerniak, 2007: 14).

Dokument lokacyjny Pyzdr nie zachował się. Został zapewne zniszczony podczas najazdu i zniszczenia miasta przez Krzyżaków w roku 1331. Pyzdry lokowano na prawie średzkim (odmianie prawa magdeburskiego) (Czerniak, 2007: 26). Pyzdry należą do miast wielkopolskich, których lokacja dokonała się najwcześniej (XIII w.). Miało to związek z rozwojem gospodarczym (przyśpieszonym rozwojem rynku towarowego i pieniężnego). Sprzyjająca lokacji miast sytuacja gospodarcza miała głównie miejsce na prawym brzegu Warty i na terenach blisko rzeki położonych. Chronologię lokacji miast Wielkopolski w wiekach średnich (wiek XIII) zamieszcza w swej pracy Oskar Lange (1925: 17-23). Tu podaję tylko - opierając się na wymienionej wyżej chronologii - datę lokacji Pyzdr i miast pobliskich:

Śródka (dziś dzielnica Poznania) - 1231 (?);

Gniezno 1235 (w każdym razie przed 1243);

Powidz - 1243;

Kostrzyn - 1251;

Poznań - 1253;

Śrem - 1253;

Kłecko - 1255 (?);

Pyzdry - przed 1257;

Kalisz - przed 1260 (po 1253?);

Pobiedziska - przed 1266;

Lądek 1269;

Kazimierz (pow. koniński) - 1287;

Słupca - przed 1290 (po 1282);

Stawiszyn przed 1291. 
Do szybkiego rozwoju ekonomicznego Pyzdr przyczyniła się między innymi polityka protekcyjna książąt wielkopolskich, Bolesława Pobożnego (żył w latach 1221-1279) i Przemysła II (żył w latach 1257-1296). Polityka ta dotyczyła nadania miastu różnych uprawnień gospodarczych i przywilejów, takich jak zwolnienie od uciążliwych danin, uposażenia gruntowe, prawo odbywania targów i jarmarków. Pyzdry należały wówczas do najważniejszych miast wielkopolskich (obok Poznania, Kalisza i Gniezna). Rozwój Pyzdr został zahamowany w wyniku najazdu krzyżackiego w 1331 roku, miasto uległo zniszczeniu (Wędzki, 2007: 78-92).

Miasto odbudowano dzięki zaangażowaniu Kazimierza Wielkiego - Pyzdry były miastem królewskim. Wieki XV i XVI to najświetniejszy okres w dziejach miasta. W wiekach późniejszych nastąpił spadek jego znaczenia - przestało być miastem powiatowym. Po powstaniu styczniowym pozbawiono Pyzdry praw miejskich - odzyskały je po odrodzeniu państwa w roku 1918 (Czerniak, 2007: 4).

Na całość utworu składają się informacje dotyczące historii Pyzdr (uwarunkowania historyczne zabytków), struktury społecznej mieszczan, przywilejów mieszczańskich, statutów cechowych. Dalsza część utworu dotyczy języka zabytków. Wprowadzone w niniejszym utworze modyfikacje wyników moich badań nad zabytkami z Pyzdr są konsekwencją kwerend będących kontynuacją kwerendy pierwotnej z roku 1991. Dalsze kwerendy miały miejsce po roku 1994 (por. Chojnacki, 1994: 184-189). Modyfikacje dotyczą uzupełnień w strukturze opisu cech językowych zabytków, nowych, istotnych obserwacji w kontekście tendencji rozwojowych i unifikacyjnych języka narodowego, licznych kontynuacji we współczesnych gwarach. Nowa kwerenda pozwala wprowadzić podrozdziały: Słowniczek i Antroponimia.

\section{Opis zabytków}

Zabytki, które prezentuję, odnalazłem w listopadzie 1991 roku w Muzeum Regionalnym w Pyzdrach, gdzie są przechowywane. Są to dokumenty potwierdzające przywileje cechów rzemieślniczych w Pyzdrach. Stan zabytków jest różny. Treść czterech spośród pięciu odnalezionych dokumentów (w tym jednego sporządzonego po łacinie), mimo wyblakłego pisma i luk spowodowanych plamami i zupełnym zatarciem, można odtworzyć.

Wszystkie dokumenty wykonane są na jednostronicowym pergaminie o zbliżonych wymiarach: długość około $60 \mathrm{~cm}$, szerokość - $43 \mathrm{~cm}$, grubość - 0,15 mm. U dołu każdego z nich zwisają na sznurach pieczęcie wykonane z wosku w kształcie miski o przeciętnej średnicy $9 \mathrm{~cm}$.

W tekście posługuję się skrótami odnoszącymi się do poszczególnych zabytków, wyrażonymi numeracją: $1-5$.

Zabytek Nr 1 (sygnatura MRP $(\mathrm{H})$ - 3). Dokument sporządzony został w Toruniu dnia 17 I 1576, podpisany przez biskupa przemyskiego, kanclerza królewskiego, Piotra Dunina. Stefan Batory potwierdza w nim statut cechu szewskiego w Pyzdrach. Wstęp dokumentu napisany jest po łacinie. Potem następuje zapis w języku polskim, w dolnej partii prawie nieczytelny (wyblakły, poplamiony). U dołu zwisa pieczęć królewska z orłem polskim 
otoczonym herbami ziem polskich, w tym herbem Litwy. Ponad koroną widnieją tarcze $\mathrm{z}$ herbami Batorego i Bony.

Zabytek Nr 2 (sygnatura MRP $(\mathrm{H})$ - 2). W dokumencie burmistrz z radą miejską potwierdzają statut cechu szewskiego w Pyzdrach. Pod polskim tekstem miejsce i datę sporządzenia dokumentu zapisano po łacinie: „Actum et datum in Praetoria Pifdren $\int i$ iftima die Mensis Februari / Anno Domini Millesimo Quingentesimo Septuagesimo Sexto".

Zabytek Nr 3 (sygnatura KSW MRP $(\mathrm{H})$ - 512). Dokument zawiera potwierdzenie przywilejów dla cechu kramarskiego przez burmistrza i radę miejską (z treści wynika, że poprzedni dokument spłonął). Po wstępie napisanym w języku łacińskim następuje czytelny tekst polski (zatarcia występują tylko na złożeniach arkusza), zakończony stwierdzeniem: „dla lep/zei pewno/ci y mocy pieczenć na/fa Miei/ka ie/t przyłożona”. Jak początek dokumentu, tak samo jego koniec zapisano po łacinie. Przytaczam pierwsze zdanie końcowego zapisu: „Actum et datum feria Jecunda ante fe/tum Jancti Micolai Anno Lm Mille/imo Quigenty Nonage/imo Primo Ex Actis Captlibus Castreiz di/trictus Pysdreif”. W ostatnim zdaniu zapisu łacińskiego stwierdza się, że przyłożono pieczęć królewską z datą w Krakowie 10 II 1595. Tekst zamyka napis „Sigismundus Rex”. Do dokumentu przywieszona jest tylko pieczęć królewska z napisem w otoku: „Sigismundus III DG Rex Poloniae MD”.

Zabytek Nr 4 (sygnatura MRP $(\mathrm{H})-4$ ). Jest to tekst polski, napisany w Nieszawie 22 XI 1590. Zygmunt III uznaje dokumenty z dnia 17 XI 1576 i 20 II 1585, którymi to Stefan Batory potwierdził statut przywileju dla cechu szewców w Pyzdrach.

Zabytek Nr 5 (sygnatura MRP $(\mathrm{H})$ - 1). Jest to dokument sporządzony w języku łacińskim. Zawiera statut cechu szewców w Pyzdrach nadany przez miasto, a potwierdzony przez Zygmunta Starego w roku 1531. Pisarze tekstów są anonimowi.

\section{Struktura społeczna mieszczan pyzdrskich w drugiej połowie XVI wieku. Ustrój miasta}

Miasta w Polsce w średniowieczu i później (XVI-XVIII) były zorganizowane na wzór niemiecki. Nastąpiło to wówczas, gdy przyjęto w Polsce w odniesieniu do miast prawo magdeburskie (Góralski, 1983: 321). Społeczność miejska dzieliła się na patrycjat, pospólstwo (ogół pełnoprawnych obywateli miasta) i biedotę plebejską (przekupnie, wyrobnicy, służba), która pozbawiona była praw przysługujących dwóm wyżej wymienionym grupom. Patrycjat to przede wszystkim wielcy kupcy. Oni głównie zasiadali w radzie miasta, toteż polityka rady służyła zwłaszcza interesom kupiectwa. Z czasem do rady wybierano także rzemieślników (Ihnatowicz i in., 1988, 1996, 1999, 2005: 130). Rada kontrolowała całą gospodarkę miasta i jego dochody. W skład rady wchodzili rajcy. Według prawa magdeburskiego wyboru nowej rady dokonywała rada ustępująca. Rada zajmowała się administracją, strzegła nienaruszalności praw i przywilejów miasta. Rajcy spośród swego grona wybierali burmistrza. Był on przewodniczącym rady i wykonywał jej postanowienia. Rada sprawowała nadzór nad cechami rzemieślniczymi (Góralski, 1983: 323). 
Szeroko o ustroju miejskim Pyzdr pisze J. Łojko (2007: 66-99). Ustrój miasta opierał się w znacznym stopniu na postanowieniach prawa magdeburskiego i przywileju lokacyjnym. Autor informuje, że już w średniowieczu Pyzdry uzyskały własny samorząd. W dokumencie z 1319 roku, potwierdzającym nadanie dla klasztoru cystersów w Lądzie, wymieniony jest skład rady miasta (rada liczyła 5 osób). Także w drugiej połowie XVI wieku obok burmistrza urzędowało 5 osób. „Istotnym elementem ustroju miejskiego był pewien cykl i rytuał prawny, do którego należy zaliczyć przede wszystkim wybory władz radzieckich i burmistrza" - pisze autor.

Ważnym elementem organizacji miasta było powstanie i funkcjonowanie cechów. Były to zrzeszenia rzemieślników, obejmujące poszczególne specjalności. Celem cechu była przede wszystkim regulacja wielkości i jakości produkcji oraz utrzymywanie na stałym poziomie cen wytwarzanych towarów. Cech też był ogniskiem życia rodzinnego i towarzyskiego. Zasady działania i zasady hierarchizacji każdego cechu określał statut (Konopczyński, 1936: 368). Działalność cechów była pod stałą kontrolą rad miejskich. Rady miejskie zatwierdzały też wybór władz poszczególnych cechów. Na czele cechu stali starsi, wybierani na ogólnym zgromadzeniu pełnoprawnych członków - mistrzów (Ihnatowicz i in., 1988, 1996, 1999, 2005: 131).

Niżej przedstawiam statut cechu szewskiego (omówienie), zawartego w przywileju z roku 1576 . W pozostałych przywilejach są podobne statuty.

Statut cechu szewskiego w Pyzdrach potwierdzony przez burmistrza i radę miejską.

\section{Zabytek Nr 2}

(omówienie tekstu oryginalnego)

Tekst oryginału zaczyna się od słów łacińskich In nomine Domini Amen. Dalej oświadcza się, że dla zachowania pamięci poniższych postanowień zachodzi potrzeba, aby je potwierdzić pisemnie w obecności świadków i przyłożeniem pieczęci. Tedy przed obliczem burmistrza Jędrzeja Sławińskiego, rajców miasta Pyzdr Wojciecha Kwaśnego, Grzegorza Grudzieńskiego, Wojciecha Krawca, Pawła Maruszki, Jędrzeja Biestrzykowskiego i całego pospólstwa wspomnianego miasta stanęli: starsi cechu szewskiego Stanisław Chudzina, Szymon Łata, czuzarowie ich przysiężni i wszyscy bracia wspomnianego rzemiosła. Pilnie ich prosili, aby nadany im (przez króla przywilej) potwierdzili.

(tekst oryginalny nie ma numeracji)

1. Cech szewski otrzymuje na wieczne czasy zbudowane przez władze miejskie jatki w celu sprzedawania w nich szewskich wyrobów. Przywilej dotyczy także szewskich potomków. Każdy szewc i jego potomkowie mają płacić na Święto Marcina, Święto Biskupa każdego roku sześć groszy do ratusza.

2. Kto będzie chciał przyjąć się do bractwa, będzie musiał wpłacić do skrzynki brackiej dwie grzywny pieniędzy, dać dwie beczki piwa i cztery funty wosku. Powinien pokazać metrykę i świadectwo urodzenia (list). Kto chce się uczyć rzemiosła, musi dać na kwartę piwa, potem będzie musiał płacić przez dwa lata osiem groszy i dwa funty wosku.

3. Wspomniane bractwo otrzymuje prawo, według którego żaden przekupień z innego miasta nie może wykupywać skór na pyzdrskim rynku. Nie mogą także wykupywać 
i Żydzi, oprócz jarmarku. Dotyczy to także wykupywania dębu i popiołu. Prawo kupna skór i dębu ma tylko ten z mieszkańców Pyzdr, kto zna rzemiosło i należy do bractwa. Nikt z innych miast, miasteczek i wsi nie może sprzedawać swoich butów w Pyzdrach. Gdy to prawo zostanie naruszone, towar ulega konfiskacie.

4. Starsi cechu i cuzarowie mają obowiązek sprawować nadzór nad jakością wyrobów. Towar złej jakości ma być skonfiskowany.

5. Żadnemu z braci nie wolno robić butów na przedmieściu. Uszyte buty na przedmieściu mają być skonfiskowane.

6. Żadnemu z braci nie wolno kupować skór, dębu i popiołu na przedmieściu. Nieprzestrzeganie tego zakazu karane jest dwoma funtami wosku.

7. Jeśli któryś z braci kupi jednocześnie dwie skóry, a inny brat poprosi go o odsprzedanie jednej, wtedy to powinien mu to uczynić pod karą dwóch funtów wosku.

8. Żadnemu z braci nie wolno kupować jednocześnie dwu wozów dębu, tylko jeden przed obiadem, a drugi po obiedzie pod karą jednego funta wosku.

9. Aby żaden z braci nie śmiał sprzedawać wyprawionych skór wieśniakowi (chłopu) pod karą pół kamienia wosku.

10. Aby żaden $\mathrm{z}$ braci nie śmiał pracować $w$ dni świąteczne pod karą dwu funtów wosku.

11. Żadnemu $\mathrm{z}$ bractwa nie wolno kupować dębu podczas mszy w niedzielę pod karą jednego funta wosku.

12. Nie wolno kupować skóry na żywym bydlęciu pod karą dwu funtów wosku.

13. Reguluje się życie religijne bractwa. Naznaczono wielkie roczne zgromadzenia (schadzki): pierwsze w niedzielę białą, drugie w niedzielę przed św. Wojciechem, trzecie w Oktawę Bożego Ciała, czwarte w niedzielę po narodzeniu Panny Maryi, piąte w dzień św. Szczepana. Który by z braci był nieobecny na wymienionych wyżej zgromadzeniach, podlega karze czterech funtów wosku.

14. Członkowie bractwa podlegają przestrzeganiu zasad moralnych. Jeśli brat zmarłego i jego bratowa po zmarłym bracie zachowują się nieprzyzwoicie, mają być usunięci $\mathrm{z}$ bractwa.

15. Który by brat żył w niezgodzie z innymi braćmi i opuścił bractwo bez zezwolenia starszych, ma dać jeden achtel piwa.

16. Żaden $\mathrm{z}$ braci nie może chodzić $\mathrm{z}$ nożem albo z kordem do bractwa pod karą jednego funta wosku.

17. Żaden czeladnik i chłopiec nie mogą kupować skór wielkich na targu lub w wolnym handlu, chyba że poproszą swego mistrza o pośrednictwo w tym kupnie (kupuje mistrz i odsprzedaje czeladnikowi lub chłopcu) - pod karą dwu funtów wosku.

18. Aby żaden nie śmiał kupować skór, dębu i popiołu samotrzeć, tylko on sam lub jego małżonka pod karą dwu funtów wosku.

19. Jeśliby się który z młodszych (braci) chciał wzbraniać się od noszenia mar, ten ma dać kary cztery funty wosku.

20. Który by brat nie przyszedł w czas na Wigilię albo do noszenia świec, kiedy z domu z ciałem wychodzą, musi dać pół grosza.

21. Który by brat odszedł od mszy (żalomszy) brackiej, odprawianej za zmarłych braci, siostry i ich dzieci - przed jej ukończeniem - ma ponieść karę zapłaty jednego grosza. 
22. Który by brat młodszy nie zapalił świecy w dni świąteczne, wtedy ma zapłacić pół grosza kary, potem ilekroć by zgrzeszył, czyli za każdy raz ma płacić jeden grosz.

23. Aby żaden z braci nie śmiał jeden drugiemu odciągać (odwodzić, namawiać do odejścia) czeladnika albo ucznia pod karą pół kamienia wosku.

24. Kiedy by który mistrz przyszedł z innego miasta i chciał przyjąć się do tutejszego bractwa, musi przynieść list z tamtego miasta pod pieczęcią mistrza - potwierdzający, że się dobrze zachował.

25. Który by brat miał dwóch czeladników, wtedy trzeciego nie może przyjmować, tylko na rzędziaka pod karą dwunastu groszy.

26. Nieczytelne (zatarcia).

27. Nieczytelne (zatarcia).

28. Nieczytelne (zatarcia).

29. Nieczytelne (zatarcia).

30. Nieczytelne (zatarcia).

31. Jeśli któryś z braci przyjdzie do innego brata targować, a transakcja nie dojdzie do skutku i ten, który przyszedł kupić, opuścił już próg i przekroczył rynsztok, nie można już go wołać z powrotem pod karą jednego funta wosku.

32. Także kiedy by kto przyszedł do brata na jatki i targowałby u niego, a targ nie dojdzie do skutku i gdy wówczas ten brat do innego pójdzie, nie wolno go powtórnie wołać pod karą jednego funta wosku.

33. Gdyby się dwaj bracia ze sobą na jatkach kłócili, wtedy każdy z osobna ma zapłacić kary dwanaście groszy.

34. Gdy jeden brat pożyczył jakąś rzecz od drugiego i gdyby mu tej rzeczy nie oddał, ma zapłacić dwa funty wosku.

35. Żaden brat nie może w jakiejś spornej kwestii dochodzić swoich praw w jakimkolwiek urzędzie w odniesieniu do innego brata, jeśli spór może być rozstrzygnięty w bractwie pod karą dwóch funtów wosku.

36. Gdyby który brat przyjął ucznia bez wiedzy bractwa, wtedy musi dokonać odpowiedniej zapłaty.

37. Gdyby jakiś chłopiec chciał pracować u mistrza, a nie uczyłby się w innym bractwie, ma zapłacić, jak inny uczeń.

38. Gdyby jakiś uczeń odszedł od swojego mistrza, po dwóch tygodniach traci członkostwo w bractwie, a gdyby znowu chciał się uczyć, musi płacić bractwu jak przedtem.

39. Żaden z braci nie może wyprawiać skór wielkich kmieciom do wsi z wyjątkiem duchownych, szlachciców i mieszczan pod karą dwóch funtów wosku. 


\section{Właściwości językowe}

O występowaniu zjawisk językowych znamiennych dla omawianego obszaru drugiej połowy XVI wieku.

Fonetyka

1. W omawianych zabytkach zauważamy odstępstwa od przegłosu. W zabytkach $\mathrm{Nr} 1$ i Nr 2 można dostrzec niekonsekwentnie przeprowadzony przegłos. Obok form przegłoszonych występują formy nieprzegłoszone: rzemieflo, rzemiefla, także wrzemieflie ( $\mathrm{Nr} 1)$; rzemiesła, rzemieszłal/rzemiosła $(\mathrm{Nr} 2)$. W zabytku $\mathrm{Nr} 4$ są tylko

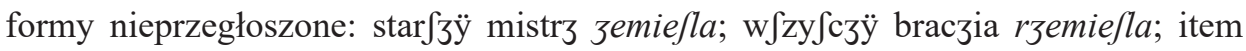

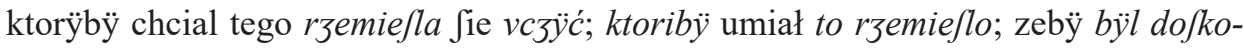
nalszz̈ w rzemieflie. „Proces cofania się form przegłosowych dokonywał się stale” (GH II 79). Miała tu miejsce tendencja wyrównywania form (są to tzw. wyrównania analogiczne). Szły one zresztą zarówno w kierunku zaniechania przegłosu, jak i rozszerzenia jego zasięgu poza zakres wyznaczony określoną regułą (GH I 78). Konsekwencje odchyleń od zasady przegłosu obserwujemy dziś przede wszystkim w gwarach: biere, niesę, piere, wieze, wiesna.

2. Kontynuacją staropolskich samogłosek długich są tzw. samogłoski pochylone $(\stackrel{\circ}{a} \dot{e}, \dot{o})$. W omawianych tekstach pochylenia nie są oznaczane. O silnie zwężonej wymowie kontynuantu stpol. $\bar{o}$ (długiego) może świadczyć kilkakrotnie pojawiający się zapis wyrazów pulkamienia (wosku), (Nr 3); pulgrosza ( $\mathrm{Nr} 2$ ) przez u. H. Wiśniewska (1975: 21) w swojej książce pisze: „Warto dodać, że wyraz pół i jego pochodne pisano w księgach przez $u$, co stanowi jednak normę tych czasów”. Czy brak konsekwencji w zapisach wyrazów pulkamienia (wosku) ( $\mathrm{Nr} 3$ ), pulgrosza $(\mathrm{Nr} 2)$ oraz w innych miejscach zabytków polgrosza (Nr 1) może potwierdzać opinię językoznawców (zob. Klemensiewicz, 1985: 285-290) o zaniku ustnych samogłosek pochylonych $\dot{e}, \stackrel{a}{a}, \dot{o} \mathrm{w}$ dobie średniopolskiej? Staropolskie samogłoski długie mają kontynuację w gwarach. W Wielkopolsce wschodniej są to kontynuacje (gwarowe):

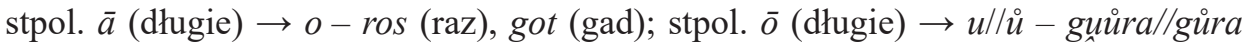
(góra); stpol. $\bar{e}$ (długie) $\rightarrow i / / y-s ́ n i k / / s ́ n ́ y k$ (śnieg).

3. Samogłoski nosowe. W poniższej tabeli pokazano, jak nosówki $(e, q)$ mogłyby być (ewentualnie) wymawiane (synchronicznie lub asynchronicznie) w odpowiednim otoczeniu fonetycznym. 


\begin{tabular}{|c|c|c|c|}
\hline \multicolumn{4}{|c|}{ Znaki (litery i połączenia literowe) zastosowane w tekście do oznaczenia nosówek $(e, q)$} \\
\hline zabytek Nr 1 & zabytek Nr 2 & zabytek Nr 3 & zabytek $\mathrm{Nr} 4$ \\
\hline$e, e, a, a m$ & $e, a, e n, a m, a m$ & $e, a, a m, e n, e ̨ n, a n$ & $e, a, a m$ \\
\hline $\begin{array}{l}\text { mezowie, pieczęci, } \\
\text { swietho, urzedowa } \\
\text { (urzędowa), wzietha } \\
\text { (wzięta), beda (będa), } \\
\text { porzadku, dzieia, } \\
\text { prӟ̈acz, Blazeÿ } \\
\text { Bamba }\end{array}$ & 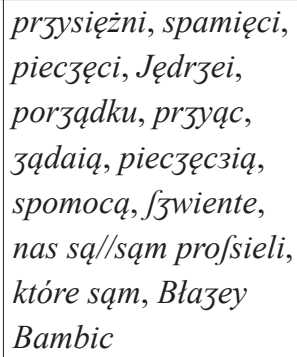 & $\begin{array}{l}\text { mężowie, naszę, wien- } \\
\text { cy, fwienta, pieczenci, } \\
\text { wstapiło, pieniądze, } \\
\text { zandaia, urzendowa, } \\
\text { benda, przyanć, nas } \\
\text { sam prosili, rzęndzić }\end{array}$ & 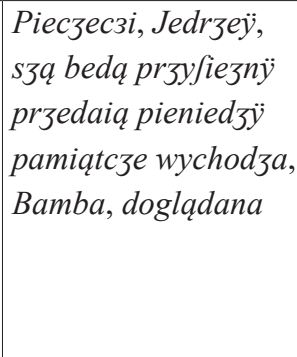 \\
\hline
\end{tabular}

Z powyższych przykładów wynika, że w zabytkach $\mathrm{Nr} 1$ i Nr 2 nosówki oznaczane są głównie przez e, e , a, a. Jednak zapisy Bamba (Nr 1) J3wiente, Bambic, sąm profsieli, które sąm ( $\mathrm{Nr}$ 2) dowodzą, że samogłoski nosowe przednia i tylna musiały mieć w odpowiedniej pozycji wymowę rozsuniętą. Zapisy nosówek w najpóźniejszym z omawianych zabytków (Nr 3) przedniej przez en, tylnej przez an przed spółgłoskami zwartymi i afrykatami świadczą o nasileniu się procesu przechodzenia na wymowę rozłożoną. Proces ten rozpoczął się najwcześniej w Wielkopolsce i trwał od XV wieku (Bargieł, 1969: 52; zob. też Kuraszkiewicz, 1986a: 180-186; Kuraszkiewicz, 1986b: 187-193). Z pisowni formy czasownikowej sq $(a \rightarrow a q m, a m)$ w zabytkach Nr 2 (sam profsieli, które sąm) i Nr 3 (nas sam prosili) należałoby wnosić o rozłożonej wymowie kontynuantu samogłoski nosowej długiej ( $Q$ - o nosowe długie) w wygłosie, co jest i dziś charakterystyczne dla wymowy gwarowej Wielkopolski (Dejna, 1973: 252). W zabytku Nr 2 dwa wyrazy zanotowano z nosówką, której dziś w tych wyrazach brak rzemięsło i mięfkaiączy (nosowość wtórna - pod wpływem poprzednika nosowego). W gwarach wschodniej Wielkopolski wymawiało się do niedawna z wtórną nosowością wyraz mixszanka ( $y$ nosowe, mieszanka zbożowa).

4. W wiekach XVI i XVII w staropolskich grupach $i l, y l$, it, yt samogłoski $i, y$ przechodziły w e. Według Z. Klemensiewicza (1985: 293) proces ten miał charakter sporadyczny, a nie powszechny. W zabytku Nr 2 panuje wyłącznie grupa z e: betyby umocznione; pilnie nas są prossieli; a ktoryby takowy bet nalezion; beła robota dogliądana; ktoryby zbraczi przerzeczonych kupiet; ktorẏbÿ zbraczi przerzeczonego bracztwa niebet; item kiedy kto przydzie targowacz bety do którego brata; ỳ gdy் by jię iez/cze niekonczeła; nieuczełby /3ię. W pozostałych zabytkach grupa z e występuje równolegle z $i l, y l,(i t, y \ell)$ : a drugi brat prosietby go $(\mathrm{Nr} 1)$; pilnie nas sam prosili (Nr 3); odfzczepieniec wiary krze cciańskiei aby nie byl przyent ( $\mathrm{Nr} 3$ ); pilnie nasz są prosilij ( $\mathrm{Nr} 4)$; bela robota doglądana ( $\mathrm{Nr} 4)$; aby bÿla wziętha ÿ niewróczona (Nr 4); kupil razem dwie skorze (Nr 4); brat profielby go (Nr 4); item ktoribÿ brath bÿl spornym (Nr 4); zebÿ bÿl dofkonalszÿ w rzemieflie (Nr 4). Do niedawna w gwarach wschodniej Wielkopolski można było usłyszeć formę wyrazową prosiemy. Forma ta pojawiała się w tekstach wygłaszanych na uroczystościach (na weselach) - w chwilach niecodziennej egzaltacji. 
5. W omawianych zabytkach językowych natrafiamy na jeden z etapów rozwojowych samogłosek $i, y$. W języku prasłowiańskim były one fonologicznie oponentne ( $i-\mathrm{wy}-$ sokie, przednie, $y$-tylne). $Z$ czasem nastąpiło przesunięcie artykulacyjne $-\mathrm{w}$ języku polskim $y$ stało się przednie, bliskie $i$. Dziś mamy tu jeden fonem $-y$ jest wariantem kombinatorycznym $i$. To $i$ ma zawsze poprzednik miękki, $y$ twardy: śiła - posyła (GH II 90-91). W wyrazie rzeczij - (Nr 1) (rzeczy, D 1. poj.) występuje zakończenie $i j$. Mamy tu przykład wzajemnego stosunku samogłosek $i, y$ w ich rozwojowym procesie fonetycznym (dwufazowa wymowa samogłoski $y$ : ij/yj). Dziś asynchroniczna wymowa samogłoski $y$ w postaci $y j$, ij jest właściwością gwarową występującą na obszarze Wielkopolski zachodniej; dotyczy to zwłaszcza zakończenia wyrazów (myšyj, złyj) (GH I 74-75). Por.: dyftongizacja stpol. $y$ : ry $y^{i} b a ~ m y^{i} j$ zły $y^{i}$ doebryj (Dejna, 1973: 250). Niżej podaję dalsze przykłady dyftongicznej wymowy samogłoski $y$ (są tu przykłady zlania się obu samogłosek w jeden dźwięk $i$ plus $j$ ): tijm (tym), ktorzij, abij (aby), przijffedszij, Sijmon latha, Sa prosilij, vtwierdzamij (utwierdzamy), daiemij (dajemy) ( $\mathrm{Nr} 1$ ). W pozostałych zabytkach (w odnośnych pozycjach) występuje $\ddot{y}$ lub $y$ : kazacz od urodzoniny uczenia; na rynku ani na wolniczy; aby zaden tuta mięskaiaczy; aby przes przerzeczone $\int \operatorname{tra} \int 3$ y $C$ zuzary beła robota dogliądana (Nr 2); w dzień fwienty Uroczysty; wielgi Mszy na nieszporze; Synowie Mistrzowscy;

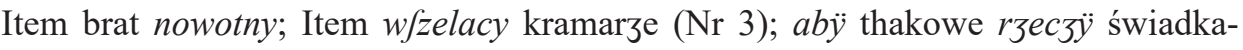

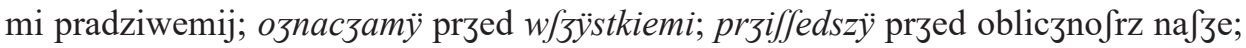

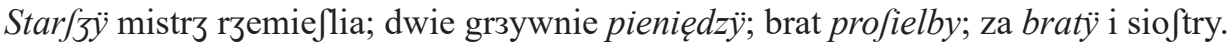

6. W omawianych zabytkach kontynuant psł. spółgłosek *l', *lj zachowuje miękkość także w położeniu innym niż przed samogłoską $i$ : liudzki («*ljudbskb) (Nr 1); wprzyrodzeniu liudzskim, mocą przywilieiu, zeby piwo rozliewał (w dwu ostatnich przykładach miękczący wpływ samogłoski przedniej e - zob. Moszyński, 2006: 2), ma onego statku doliacz, sliachcziczom y miefzczanom ( $\mathrm{Nr} 2)$; w przyrodzeniu liudzskiem,

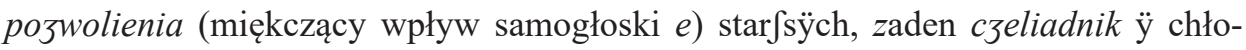
piec3, zebÿ bÿl dofkonalszÿ w rzemieflie (miękczący wpływ samogłoski e) (Nr 4). Pojawia się też już kontynuant w postaci $l$ (twarde) (Nr 3): przyrodzeniu ludzkim pożytki. Według GH I 151 zachowanie miękkości kontynuantu psł. spółgłosek *l’, *lj także w położeniu innym niż przed samogłoską $i$ w XVI wieku jest już sporadyczne. $\mathrm{Tu}$ (w zabytkach $\mathrm{Nr} 1, \mathrm{Nr} 2, \mathrm{Nr} 4$ ) - powszechne.

7. W omawianych zabytkach można dostrzec zapisy form przymiotników i zaimków

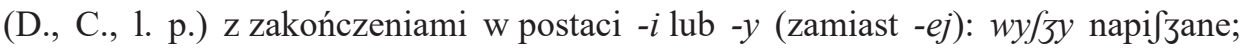
okrom prozby w/zelaki; od $\int$ edł odem $\int 3$ braczski; ku wiekuifty rzeczy ty pamiątce; niemaiącz zadny winny ( $\mathrm{Nr}$ 2); stuszny zandaią; wiency ( $\mathrm{Nr} 3)$. W zabytku $\mathrm{Nr} 3$ są też formy wiekuiftei, brackiej, kramarskiej. W zabytku $\mathrm{Nr} 1$ są tylko formy z koń-

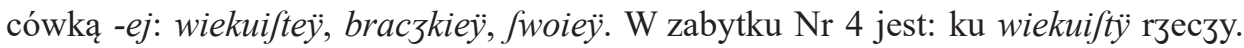
W kilku przykładach instr. sing. neutr. rzeczowników występuje końcówka -im, np. Bozym Narodzenim. Pojawiające się w zakończeniach -ej, -em samogłoski $i, y$ świadczą o silnie zwężonej wymowie samogłoski $\dot{e}$ (pochylonej), kontynuantu stpol. samogłoski $\bar{e}$ (długiej). Dziś w gwarach wschodniej Wielkopolski w odnośnej odmianie przymiotników i zaimków jest zawsze końcówka -y lub -i (zależnie od wygłosowej 
spółgłoski tematu: twarda czy miękka), na przykład: czerwuny cegły, dobry roboty; bioły koszuli; zdrowy żywności, suchy bilizny; tani kiełbasy, słodki herbaty; psi (psiej) duszy itd. Końcówka -im (instr. sing. neutr. rzeczowników) funkcjonuje w dzisiejszej gwarze mieszkańców miasteczek Kleczewa, Ślesina, Sompolna (pogranicze wielkopolsko-kujawskie - wpływ gwar kujawskich - por. Sobierajski, 1952): pisanim (pisaniem) listu; picim (piciem) piwa; gaszynim (gaszeniem) pożaru; mówinim (mówieniem) głupstw; pranim (praniem) ubrania; moim zdanim (zdaniem); długim kazanim (kazaniem); jechać pociungim (pociągiem); najeść się punczkim (pączkiem); łatwym zarobkim (zarobkiem) itd.

8. Kontynuanty stpol. ir pochodzące z *'́ przeszły w er we wszystkich czterech zabytkach: napierwe ÿ ( $\mathrm{Nr}$ 1), pierwa, pierwy, napierwy ( $\mathrm{Nr} 2)$ napierwy $(\mathrm{Nr} 2)$; pierwy napierwy (Nr 3); napierwÿ (Nr 4). Także kontynuanty przedpolskiego *ir//*yr przeszły w er lub erz: czterech, czterÿ (Nr 1); czterzech niedziel; czterzy (Nr 2); w czterech niedziel ( $\mathrm{Nr} 3)$.

9. Stare grupy (prasłowiańskie) $*_{s} \dot{r}, *_{z} \dot{r}$, *žr występują w języku polskim do połowy XV wieku jako śrz i źrz. Późniejsze zmiany w kontynuantach powyższych grup mają charakter dialektalny (Śmiech, 1953: 115-116). W Wielkopolsce utrzymują się stare śrz (śrzoda, Śrzódka - dzielnica Poznania) i źrz (źrzódło). Wynotowałem tylko dwa przykłady z kontynuantami pierwotnych grup *śr i $*_{z} \dot{r}$. Kontynuant grupy *sŕ ma postać śrz (we frzodę pierwszą suchodzienną, $\mathrm{Nr} 3$ ), a kontynuant grupy *zŕ występuje jako -jrz- (podeirzenia, Nr 3) (por. Śmiech, 1953: 49-50). Wielkopolskie kontynuacje śrz, źrz (-jrz-) przejął szesnastowieczny polski język literacki. W XIX wieku ukształtowały się funkcjonujące dziś kontynuacje dawnych grup ( ${ }^{*} s \dot{r}$, $\left.*_{z} \dot{r}, * z ̌ r r\right)$ w postaci śr, źr, -jrz- (Śmiech, 1953: 155-158).

10. Proces upowszechnienia - 'ov- po spółgłoskach miękkich (czyli zastępowanie - 'evprzez - 'ov- w tych pozycjach) nie został jeszcze na terenie Wielkopolski w końcu XVI wieku w pełni dokonany (por. Kuraszkiewicz, 1951; Klemensiewicz, 1985: 53-54). Świadczą o tym przykłady zabytków Nr 3: córkę mistrzowska i syn mistrzewski; ale synowie mistrzowscy, wiefniaczowi, Nr 1; przedawacz skor wÿprawnÿch wiefniaczowi, Nr 4. Wynotowałem z zabytku Nr 1 przykład, w którym koń-

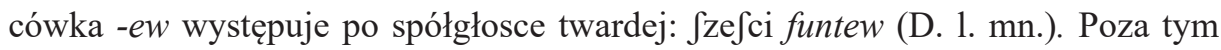
D. 1. mn. ma postać funtow. Czy pojawienie się formy funtew może świadczyć o zapoczątkowanym procesie dyftongizacji $o$, co jest typowe dla dzisiejszych gwar wielkopolskich (Bargieł, 1969: 106)? W Wielkopolsce północno-wschodniej często można spotkać nazwy miejscowe z przyrostkiem - 'ew: Bieniszew, Kleczew, Kozarzew, Sławoszewek, Suszewo.

11. Występowanie w zabytkach form wyrazowych /3wieczkiego (rzemiesła /3wieczkiego) wiąże się z rozwojem tzw. jerów (w zabytku Nr 4 - swieczkiego). Jery były to w języku prasłowiańskim półsamogłoski (zgłoskotwórcze - krótsze od innych samogłosek). Oba jery (twardy $b$ i miękki $b$ ) jeszcze w dobie prasłowiańskiej mogły występować albo w pozycji mocnej, albo w pozycji słabej. Konsekwencją rozwojową jerów był zanik jerów słabych już w najdawniejszej polszczyźnie. Stąd pol. szwiec $\left(\leftarrow *_{S \zeta b}^{b} v b c\right)$. Dzisiejsza postać szewc jest rezultatem wyrównania mor- 
fologicznego tematu mianownika do tematu przypadków zależnych (szewca

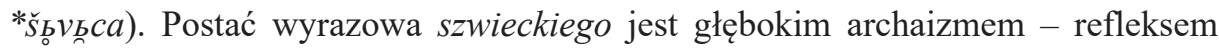
dawno zakończonego procesu rozwojowego jerów.

12. Brak przykładów przejścia $c h w \rightarrow f$. W zabytkach $\mathrm{Nr} 1$ i Nr 3 występują tylko formy z chw: chwała (Nr 1), chwale (Nr 3). W zabytkach $\mathrm{Nr} 2$ i Nr 4 brak przykładów $\mathrm{z}$ grupą $c h w$. Zapis formy B. 1. p. r. ż. kwarta w postaci kforte (dacz na kforte piwa) w zabytku Nr 2 zdaje się sugerować, że w grupach $c h w, k w, s w, t w$ pisarz wymawiał spółgłoskę $w$ bezdźwięcznie. Por. stpol. kwarta 'czwarta część jednostki miary wyższego rzędu'; a. ciał płynnych 'czwarta część garnca' (Sstp. III, z. 6, 474). Dziś wyraz kwarta rzadko używany; forma gwarowa kworta - też rzadka. We wschodniej Wielkopolsce funkcjonuje jeszcze forma kwaterka ( $1 / 4$ litra): kwaterka wody, kwaterka wódki.

13. Występuje jeszcze stara postać wyrazu tuta (bez wygłosowej j) ( $\mathrm{Nr} 2$ ): aby żaden tuta mięskaiączy. W zabytku Nr 3 jest także forma przymiotnikowa tuteczny: tutecznei roboty.

14. Z zabytku Nr 2 wynotowałem wyodrębnienie się j przed spółgłoską palatalną (antycypacja miękkości) w następujących formach: przedmiei $\int c$, przedmieifzcziu (zaden niefmiał robizc botow naprzedmieifscz; aby zaden 3 braczieÿ nie 3 zmiał kupowacz skor dębu y popiołu na przedmiei/3cziu), co jest i dziś wielkopolską cechą gwarową (por. ńejśejće, ćojća) (Dejna, 1973: 249).

15. W omawianych zabytkach występuje forma wyrazowa kozdy: tedy za kozdy ras grosz ieden. Od XIV wieku powszechna, wypierana z języka literackiego od XVI wieku przez każdy zapewne pod wpływem cz. každý (SławskiSEJP II 114). Dziś kozdy gw.

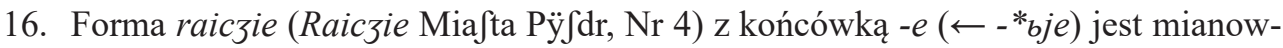
nikiem 1. mn. (należą tu także takie formy rzeczowników osobowych tematów na -jo, jak: krole, męże, bogacze, pieniacze, GH I 276-277). Jest też raiczy (z końców-

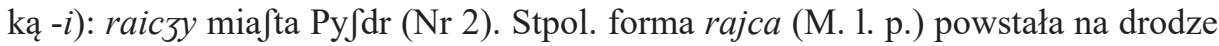
rozwoju prasłowiańskiej grupy ${ }^{*} t^{\prime} c$ : rajca $\leftarrow$ radźca $\leftarrow{ }^{*} r a d b c a$. Dzisiejsza forma radca jest rezultatem ,nowych skojarzeń morfologicznych poza działaniem dawnej zasady fonetycznej" (GH I 133).

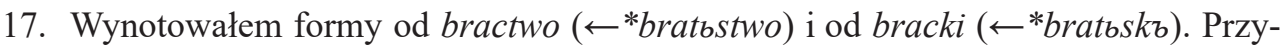
kłady: przerzeczonemu bracztwu (Nr 1); przerzeczonemu braczstwu (Nr 2); item ktorÿbÿ brat odfsedł odem $\int 3 y$ braczski $(\mathrm{Nr} 2)$.

18. Występuje wyraz oracki w formie zależnej: na oracz/kim piwie ( $\mathrm{Nr} 2)$; oracki (Ł*oračb) 'będący w związku z oraczem, qui ad oratorem pertinet' (Sstp. V, z. 8, 623).

19. Oboczność się//sie. Według M. Bargieł (1969: 73-75) w Wielkopolsce w pierwszej połowie XVI wieku w każdej pozycji (przyczasownikowej i poprzyimkowej) występują tylko formy z nosowością mię, cię, się. W omawianych zabytkach można rozpatrywać tylko formę zaimka zwrotnego się, gdyż brak przykładów na formy acc. sing. zaimków osobowych ja, ty. Trudno o wniosek po analizie tekstu zabytku $\mathrm{Nr}$ 1, gdyż samogłoska przednia oznaczana jest w nim głównie przez $e$. W zabytkach Nr 2 i Nr 3 znajdujemy tylko przykłady występowania zaimka się w pozycji przyczasownikowej. W zabytku Nr 2 są tylko formy z nosowością: chcziat, szię, 
Jзię mu podoba, rzeli $\int_{3} i e ̨$ mи dobrze zachowat, gdyby fsię wadzieli, się rzędzicz, zeby fsię iefzcze niefkonczeta, nieuczetby fзię ucзycz. Natomiast w zabytku $\mathrm{Nr} 3$ trzy razy użyto formy się (z nosowością) i siedem razy formy sie (bez nosowości). Przykłady z się: gdzie się czego wiency nie wstapiło, gdy się stużba Boża dokonczy, niewazyl fię. Przykłady z sie: które fie dzieia, iakoby sie w tym bractwie rzęndzić y sprawować mieli, nie wazyl sie, aby fie nie wazyl, gdyby fie targnal, targnela fie, pierwy sie zgodzil. Przykład z sie z zabytku Nr 4: gdysz wprzÿrodzeniu liudzkim porzytki ÿ rzeczÿ te które sie za cza Jsow dzieią. Może zapisy z sie (bez nosowości) świadczą o tym, że rozpoczął się powolny proces osłabienia i zaniku rezonansu nosowego $e \mathrm{w}$ wygłosie? Inne, wprawdzie rzadkie, formy wyrazowe zapisane w tekście bez oznaczenia nosowości $e$ w wygłosie mogłyby potwierdzać to przypuszczenie (por. Bargieł, 1969: 75). Obok form we frzodę, dziecię, polowicę, córkę, stużbę odnajdujemy żone, robote, $w$ niedziele $(\mathrm{Nr} 2)$.

20. Na przełomie XVI i XVII wieku doszło do zmiany artykulacji przedniojęzyko-zębowej spółgłoski $t$. Zaczęto stopniowo wymawiać tę spółgłoskę jak niezgłoskotwórcze $u$ (Walczak, 1995: 122). W omawianych zabytkach tylko w jednym wyrazie pojawiło się w odpowiedniej pozycji $u$ (ł): która byua sprawowana za braty $\dot{\mathrm{y}} \int 30$ ftry (Nr 2). W pozostałych wypadkach jest $t$.

21. Opozycja między szeregami $s, z, c, z$ i $\breve{s}, \check{z}, \breve{c}, 3$. Ortografia zabytków $\mathrm{Nr} 1$ i $\mathrm{Nr} 2$ jest średniowieczna i z tego względu trudno definitywnie stwierdzić, czy pisarze wymienionych dokumentów nie mazurzyli. Na przykład w zabytku Nr 2 dwuznak $c_{3}$ oznacza spółgłoski c ć, č (vmocznione, Krawiecz, fchadzcze, obliczno/scz, rzeczy, pieczęczi, ça/sy), dwuznak $\int s$ może oznaczać spółgłoski ś i š (obliçno/scz, nafsę, przy/sedszy), dwuznak $\int 3$ może oznaczać spółgłoski s i š (zemie/zła, szkrzỳn$k i$, Maru/ $3 k a$, w $3 y s t k i e$, gro/3y). O braku konsekwencji na przykład w oznaczaniu spółgłoski $s$ niech świadczy zapis miękaiąçy (mieszkający). Natomiast ortografia zabytku $\mathrm{Nr} 3$ jest ujednolicona i opozycja między szeregami spółgłosek $s, z, c, 3$ i $\check{s}$, $\check{z}, \check{c}$, ̌̆ wyraźnie zaznaczona. Jednak należy dodać, że pisarz dokumentu Nr 3 znak diakrytyczny nad $\check{z}$ często opuszcza. Oto przykłady: kozdy//każdy, wazyl się//wa$\dot{z} y c ́$, takzel/także, zaden//żaden (przy czym zapis żaden zdecydowanie przeważa), nalezq. W wygłosie $\check{z}$ często oznaczone jest przez $\int 3, s z$ (pisownia fonetyczna): tefz, tegosz, gdysz.

22. Identyfikacja kontynuantu $* \dot{r}(\rightarrow \check{r})$ i $\check{z}$. Następujące zapisy świadczą o nieodróżnianiu wymowy $\check{r}$ i $\check{z}$ : rzemiesła//rzemiosła//zemieszła (Nr 2). Identyfikacja kontynuantu $*_{r}$ $(\rightarrow \check{r}) \mathrm{i} \check{z}$ dokonała się najwcześniej w Wielkopolsce (Kuraszkiewicz, 1986c: 83-91).

\section{Morfologia}

1. Utrzymuje się wielkopolska postać przedrostka $n a-\mathrm{w}$ formach napierweÿ, napierwy

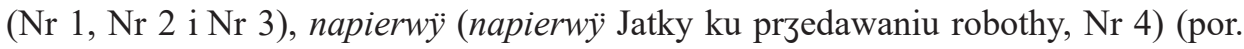
Bargieł, 1969: 106). Od XVII wieku przeważa już przedrostek naj- (wpływ dialektu mazowieckiego). W dzisiejszych gwarach wschodniej Wielkopolski omawiany przedrostek ma postać noj- (z o- kontynuantem stpol. $\bar{a}$ długiego): nojpiyrw, nojdali, nojlepi, nojładniejszy itd. 
2. W tekstach omawianych zabytków zachowała się osobliwa forma narzędnika 1. mn. rzeczownika. Z zabytku Nr 2 wynotowałem formę miftrzimi. GH I 283 podaje informację o występowaniu formy narzędnika 1. mn. mistrzmi (XVI wiek), także o innych rzeczownikach mających tę samą formę, np. kluczmi, wieprzmi, końmi, nożmi, obyczajmi, żotmierzmi. Forma ze wspomnianego wyżej zabytku miftrzimi jest o jedną sylabę dłuższa od wymienionych wyżej. Według W.R. Rzepki formy z mi- funkcjonowały dawniej (XVI-XVIII wiek) wyłącznie w języku poetyckim (,niemal zupełna ich nieobecność w prozie i absolutny ich brak w aktach sejmikowych”). Poświadczona jest ich równoczesność chronologiczna z narzędnikiem na -ami (...w XVI wieku ekspansja -ami okazała się zjawiskiem o ogromnej dynamice) (Rzepka, 1985: 96-97). Końcówka -ami (N. 1. mn. rzeczowników) jest pochodzenia prasłowiańskiego. Powstała w wyniku przekształcenia się trójczłonowej budowy praindoeuropejskich form w prasłowiańską dwuczłonową (*vod -ami) (Moszyński, 2006: 253). Zunifikowana forma $\mathrm{z}$-ami funkcjonuje też w zabytkach pyzdrskich (sjwiadkami prawdjiwymi).

3. W zabytkach pyzdrskich przykuwa uwagę forma narzędnika 1. mn. dwu rzeczowników: czas i słowo (stan odziedziczony z języka prasłowiańskiego). Oto przykłady: cza s $\ddot{y}$ wiekuiftemi ( $\mathrm{Nr} 1)$; cza sy wiekuistym ( $\mathrm{Nr} 2)$; czafy wiekuistymi ( $\mathrm{Nr} 3$ ); wadzieli słowy (Nr 2); złemi słowy (Nr 3). W.R. Rzepka (1985: 98) sądzi, że formy narzędnika typu strzały jadowitemi od XVI wieku były już właściwe językowi literackiemu. Zupełna jest ich nieobecność w aktach sejmikowych, w źródłach rękopiśmiennych - dokumentujących ówczesną kancelaryjno-urzędową odmianę polszczyzny. W obecnej polszczyźnie zachował się tylko jeden z dawnych typów form narzędnika 1. mn. rzeczowników tylko w dwóch następujących frazeologizmach: dawnymi czasy i innymi słowy.

4. Wynotowałem różne postacie formy miejscownika 1. p. wyrazu wolnica. W zabytku Nr 1 jest na wonicze (-e $\leftarrow$ *-ě): aby Rzezniczÿ na Wolnicze nieprzÿwozili. W zabytkach Nr 2 i Nr 3 występuje forma na wolniczy. GH I 291 informuje, że polska końcówka -e $\left(\leftarrow *_{-}\right.$e`) Msc. 1. p. w odmianie rzeczowników żeńskich samogłoskowych utrzymuje się w odniesieniu do twardotematowych (ręka, droga, pycha, krzywda, głowa, chwała, glina), na przykład ręce, drodze, pysze, krzywdzie, głowie, chwale, glinie (XIV wiek). Natomiast rzeczowniki miękkotematowe zachowują prasłowiańską końcówkę - *i, która po spółgłoskach stwardniałych przechodzi w y: nadziei, ziemi, woli, okolicy, dziewicy, świecy (XIV wiek). W omawianych zabytkach zachodzi przewaga zunifikowanej formy z końcówką -i//-y.

5. W zabytku Nr 3 występuje osobliwa forma rzeczownikowa kamion: pod winą czterech kamion (dotyczy wyrazu, który ma dziś postać mianownikową kamień). Jest to stpol. forma dopełniacza 1. mn. Prasłowiańska podstawa rozwojowa jest następująca: M. 1. p. *kamy; B. 1. p. *kamenb. W staropolszczyźnie po zaniku jeru (b) biernik ma postać kamień, który przejmuje też funkcję mianownika (M. = B.). Psł. D. 1. mn. *kamenz (po zaniku jeru $\boldsymbol{b}$ ) $\rightarrow$ kamion (wyrównanie do dopełniacza z tematem spółgłoskowym) (GH I 275-279).

6. Dość licznie występują w omawianych tekstach dualne formy imienne. Brak jest natomiast dualnych form czasownikowych. Te rzeczownikowe formy liczby podwójnej, 
odziedziczone z prasłowiańszczyzny, w języku staropolskim powoli zanikają. Znaczenie podwójności zachowują tylko w strukturze z udziałem liczebnika dwa. Bez tego udziału przechodzą w postać i znaczenie liczby mnogiej. Prezentowane teksty z drugiej połowy XVI wieku stanowią o dużej jeszcze funkcyjnej żywotności omawianych struktur. Przedstawiam ich wykaz: kupiç $d w u$ wozu debu (deklinacja męska); dwie grz̈̈wnie pieniedzÿ; dwie beczcze piwa; na kazde dwie Niedzieli (deklinacja żeńska) (Nr 1); ktoryby brat miał $d w u$ czeliadniku; pod winną $d w u$ funtu wosku; $d w u$ wozu debu (deklinacja męska); ktoryby zbraczi przerzeczonych kupieł razem $d$ wie skórze; dwie liećzie; przÿdzie na dwie niedzieli (deklinacja żeńska) (Nr 2); kupic3 $d w u$ wozu dębu (deklinacja męska); dwie grzywnie pieniędzÿ; dwie beczcze piwa (deklinacja żeńska) (Nr 4). Oto struktury z udziałem form (liczebnika $d w a) d w u$, $d$ wie, które nie mają już znaczenia podwójności (formy rzeczownikowe przyjmują postać liczby mnogiej): dwu funthow vofzku (Nr 1); dwie beczki piwa (Nr 2); pod wina dwu funthów wofzku (Nr 4). Dziś zachowały się relikty w nazwach par części ciała, przy czym w odpowiednich formach deklinacyjnych mają albo znaczenie liczby pojedynczej (Msc. $-w$ ręku), albo liczby mnogiej (M. - ręce, D. - oczu, uszu, N. - rękoma, oczyma, uszyma). Zachowała się do dziś forma dualna w przysłowiu: mądrej głowie dość dwie słowie. GH I 310, omawiając formy mianownika i biernika 1. p., zamieszcza informację: ,[...] końcówka -y może wskutek fałszywych skojarzeń zastąpić prawidłowe - , np. rozdzieliłasta sie dwa braty". W zabytku $\mathrm{Nr} 1$ forma braty ma znaczenie liczby mnogiej za braty ÿ sioftrÿ zmarłe.

7. W wiekach XV-XVII trwa mieszanie końcówek narzędnika 1. p. (r. m. i n. odmiany złożonej przymiotników): -ym//-im i -em, GH I 331; w 1. mn.: -ymi lub -emi (dziś -ymi bez względu na rodzaj), GH I 336. W zabytkach pyzdrskich też brak konse-

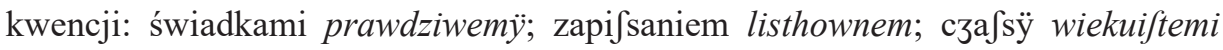
(Nr 1); napifanim liftownym; czafsy wiekuistymi; item ktoryby brat beł spornym

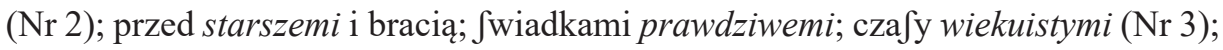

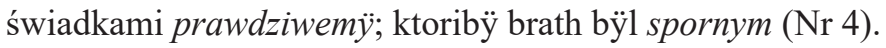

8. W XVI wieku, a już szczególnie w XVII wieku, kształtowało się przeciwieństwo rzeczowników osobowych i nieosobowych. Przykłady z końcówką -owie odmiany męskoosobowej w omawianych zabytkach są następujące: Sławni mezowie; ich potomkowie ( $\mathrm{Nr} 2)$; sławni mężowie ( $\mathrm{Nr} 3)$.

9. W B. 1. mn. r. m. (w zakresie przymiotników miękkotematowych) zachowuje się stara końcówka $-e \leftarrow-\dot{e} \leftarrow-\bar{e}(\leftarrow *$ *ějee): przes przerzeczon Star/ze (Nr 1) GH 1335.

10. Wynotowałem liczne przykłady odmiany rzeczownika o znaczeniu zbiorowym bracia ( $\longleftarrow$ *bratbja): braczia (M.) rzemiefla przerzeczonego; robota doglądana vbracziey (D.); zaden zbracziey (D.) (Nr 1); mszą suchodzienną za bracia (B.) zmarłą; przed starszemi y bracią (N.) tego cechu powinien go okazać; wfzystko wolno bendzie pobrać przerzeczony braciei (C.) spomocą urzendową; s przerzeczoną bracia (N.) (Nr 3); bela robota doglądana vbraczië̈ (D.); ktorÿbÿ zbraczieÿ (D.) (Nr 4). Różne formy przypadków rzeczownika bracia (w znaczeniu zbiorowym) występują we wszystkich czterech zabytkach, przy czym najwięcej jest form dopełniacza. W dwóch wypadkach na formę liczby mnogiej wyrazu bracia wskazują 
formy wyrazów, z którymi bracia łączy się w związkach syntaktycznych: item gdyby $\int$ zię $d w a$ braczia wespół na iatkach wadzieli słowy ( $\left.\mathrm{Nr} 2\right) ; \ddot{y} w \int z y \int c z \ddot{y}$ brazia rzemiefla przerzeczonego (Nr 4). W następujących przykładach wyrazy mają formę liczby mnogiej: ktoryby zbraczi przerzeczonych kupieł (Nr 2); za braẗ̈ ÿ sioftry (Nr 4). Proces przechodzenia od pierwotnego znaczenia zbiorowego formy bracia do znaczenia liczby mnogiej był długotrwały. Dziś gwarowa końcówka wyrazu bracia jest kontynuacją stpol. samogłoski $\bar{a}$ (długiej): braciå lub bracio.

11. Z form zaimkowych przykuwa naszą uwagę biernik r. ż. 1. p. naszę: przy ssedszy przed oblicznofscz nassę (Nr 2); jako przyszedwszy przed obliczność naszę (Nr 3);

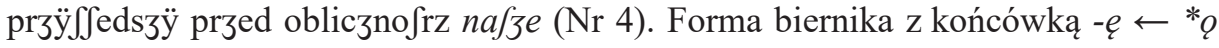
występuje od XV do XVI wieku. Zmiana nastąpiła dopiero w drugiej połowie wieku XIX, kiedy ustaliła się końcówka -ą, przejęta z formy biernika odmiany przymiotnikowej (GH I 315); postać ta funkcjonuje do dziś. W gwarach wschodniej Wielkopolski - $a$ wymawiane jest asynchronicznie (-om).

12. W omawianych zabytkach występują nieliczne formy odmiany liczebników: dać $\int z e \int c z$ (B.) gros $\int \mathrm{y}(\mathrm{Nr} 3)$; $\int z e \int c i$ (D.) funtow ( $\left.\mathrm{Nr} 3\right)$. Jest to odmiana taka sama, jak rzeczowników o tematach -i-, kontynuowana z czasów prasłowiańskich aż do XVI wieku, GH II 292. Inne formy: trzy grofe (B.) (Nr 3); winą czterech (D.) ka-

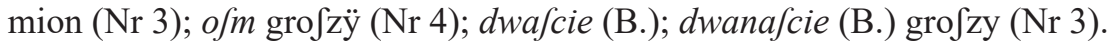

13. Wynotowałem formy czasu zaprzeszłego. Składają się one z formy słowa posiłkowego $s a$ oraz form imiesłowu przeszłego czynnego drugiego rodzaju męskoosobowego. Występują w następujących zabytkach: pilnie nasz sa prosilij (Nr 1); pilnie nas sa pro/sieli; sa pedali artikuły ( $\mathrm{Nr} 2$ ); pilnie nasz sa prosilij ( $\mathrm{Nr} 4$ ). Po okresie staropolskim występują rzadko i pełnią już funkcję zwykłego czasu przeszłego.

14. Z zabytku Nr 1 wynotowałem formy odmiany niezłożonej imiesłowu biernego: byl naliezion albo przefwiadczon. Dziś te formy trwają jako archaizmy w tekstach modlitewnych: umęczon, ukrzyżowan, pogrzebion (GH I 386).

15. Połączenie formy gen. sing. zaimka swój z odpowiednią formą rzeczownika mistrz ma postać: swe miftrza (Nr 2). Postać swe jest formą gen. sing. fem. funkcjonującą w XIV-XVI wieku (np. swe głowy) GH I 283. Mamy tu wyjątkowe połączenie zaimka żeńskiego z rzeczownikiem męskim. Powinno być swego mistrza: Zaden thowarzis aby nye sromocził swego mistrza (Sstp IV, z. 4, 288).

\section{Słowniczek}

burmistrz (niem. Bürgermaister) - 'wysoki urzędnik miejski pełniący funkcję głowy miasta; (później przewodniczący zarządu miasta)', SWO 99: Burmistrzftrz z Rada

potrzeb - 'potrzeba', ReczekPSdp. 360; potrzeb 'należy, wypada, trzeba', Sstp. VI, z. 7(40) 495: potrzeb tedÿ ie $\mathrm{t}^{2}$

\footnotetext{
${ }^{2}$ Ten i kolejne cytaty pochodzą z tekstów zabytków pyzdrskich.
} 
przerzec - 'wyżej wymienić, wspomnieć', Sstp. VII, z. 3(43), 175: Miafta przerzeczonego; przerzeczonÿch Jatek; przerzeczonemu bracztwu

przÿklonnj (przykłonny) - 'skłonny, skory', ReczekPSdp. 394: będacz przÿkklonnj

rathu $\mathbf{z}$ (ratusz, niem. Rathaus) - 'budynek będący dawniej siedzibą miejskich władz administracyjnych, także sądu miejskiego, zwykle położony w centrum miasta', SWO 627

funth (niem. Phund z łac. pondo) - 'jednostka wagi obowiązująca w wielu krajach, dawniej także w Polsce, równa wadze od $350 \mathrm{~g}$ do 560 g’: czthery funthÿ wo fku SWO 238

kloda (kłoda) - 'beczka, kadź', ReczekPSdp. 158: powinien dacz na klode piwa

wolnicza (wolnica) - por. wolny, 'wszystkim dostępny, publiczny', Sstp. X, z. 4(64), 293: abÿ Rzezniczÿ na wolnicze nieprzÿwozili

achtel (niem. Achtel - ósma część, ósemka) - daw. 'miara ciał płynnych i sypkich, ósma część beczki; beczka niewielkich rozmiarów”, SWO 4: ieden achtel piwa

çuzarowie - (kontekst językowy wskazuje, że może dotyczyć określenia osób pełniących funkcje kontrolującą i ochraniającą): Czuzarowie ÿch przyfieznÿ; aby przes przerzeczone ftra $3 \dot{y}$ Czuzary beła robota dogliądana

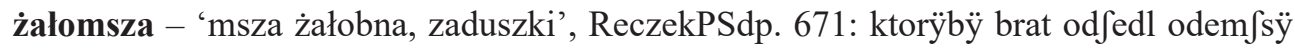

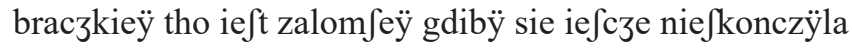

wina - 'kara pieniężna, grzywna' (por. Wiśniewska, 1975: 112): ma dacz winÿ polgro〕za schaczka (schadzka) - 'spotkanie, zebranie, zgromadzenie', ReczekPSdp. 440: Item te 3 przerzeczonemu bracztwu naznaczamy $\int$ chaczki roczne wielgie

okrom - 'bez, oprócz, poza, z wyjątkiem', ReczekPSdp. 292; jeszcze w użyciu w pierwszej połowie XX wieku krom albo okrom 'prócz, oprócz, wyjąwszy', SW II 559; krom przestarz. '[...] z wyjąatkiem' SJPD III 1151; okrom przestarz. 'oprócz, prócz; z wyjątkiem,

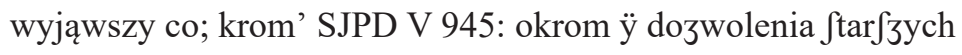

urodzonina - tu: od urodzenia: kazacz od urodzoniny uczenia

fzilaka - tu: 'konfiskata na rzecz bractwa': wolno taką robote w $\int 3$ iłaką bracz; aby za-

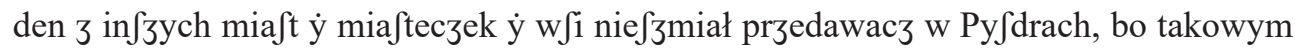
przerzeczonemu braçstwu wolno taką robote w $\int$ ziłaką braç

krzefciański - 'chrześcijański’, ReczekPSdp. 173: item aby zaden Heretik Luter Pikarch

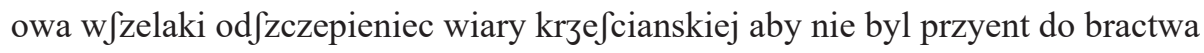

Pikarch, zob. Pikart - 'zwolennik Wiklefa, wiklefista, brat czeski, husyta', SW IV 187:

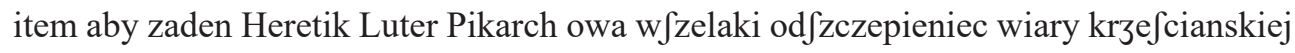
aby nie byl przyent do bractwa

nowotny - 'nowy, nowoczesny, najnowszy', ReczekPSdp. 259: item brat nowotny

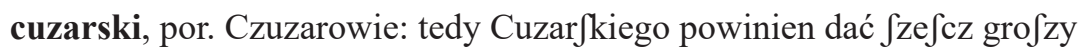


polowica (połowica) - 'połowa', ReczekPSdp. 345: ten niepowinien dać iedno tego polowicę trзy grofzi

powzdany, por. powzdać - 'przekazać, zdać', ReczekPSdp. 365: ich potomkom powzdane niedziela - 'tydzień', ReczekPSdp. 241: dwie niedzieli; w niedzielie po narodzeniu pannÿ Marÿei

czeliadnik - 'sługa, wyrobnik dworski', ReczekPSdp. 53: zaden czeliadnik ÿ chlopiec3 brat - 'wyzwolony uczeń, towarzysz' (Wiśniewska, 1975: 109): za bratÿ ÿ siostrÿ zmarle. Item ktory்by brat od $\int 3 e d ł$ odem $\int 3 y$ braczski to iest zalom $\int 3 e$

pozyrzeć - (kontekst językowy wskazuje, że może dotyczyć określenia czynności zaciągania pożyczki): Item kiedyby ieden brat u drugiego pozyrzeł iakiech rzeczẏ potrzebny்ch albo gratow

kolacyą uczynić, por. dać kolację - 'spełnić jeden z warunków wyzwolenia' (Wiśniewska, 1975: 110): Item kto chce przerzeczone bractwo przyanć ma dać do bractwa dwa złote monety Polski, y kolaccyą uczynić temu bractwu, które kosztu wiency nie ma wynosić tylko dwa złote

jatka - 1.'buda, budka, szałasik'; 2. 'kram, stragan, sklep', ReczekPSdp. 138; Wiśniewska (1975: 110) podaje następującą informację: jatki 'kramy przekupniów’: przerzeczonych Iatek; sąm wierzchem na iadkach; Item gdyby Jzię dwa braczia wespoł na iatkach wadzieli słowy

list - 'metryka, świadectwo' (Wiśniewska, 1975: 110): Potym ma mieć list od urodzain y przed starszemi y bracią tego cechu powinien go okazać w czterech niedziel po przyenciu bractwa pod winą pułkamienia wosku

oblicznofcz (obliczność) - 'twarzą w twarz, obecnie, osobiście' (Wiśniewska, 1975: 110): kthorÿm tego potrzeb iefth wiedziecz tijm kthorzij teraz sza ij napotem beda abij o thijm

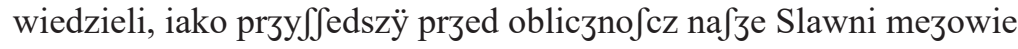

pospolstwo (pospólstwo) - ‘towarzystwo, społeczeństwo’ (Wiśniewska, 1975: 111): ij ws3y〕ztko pospolstwo Miasta przerzzeczonego

bractwo - 'stowarzyszenie, korporacja', SW I 198: aby zaden nie Jmial kupować ani przedawać tylko to przerzzeczone bractwo kramarskie

skrzynka - 'skrzynka, w której przechowywano przywileje i skarb cechu' (Wiśniewska,

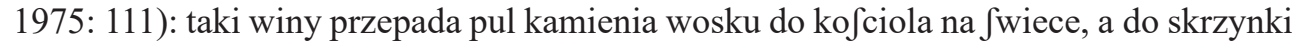
brackiej dwana $\int$ cie gro $\int 3 y$

odwabiać - 'odciągać, odwodzić, namawiać do odejścia od kogoś, czegoś', Sstp. V, z. 7(31), 507: Item by zaden sprzerzzeczonych braczi nie $\int 3 m i a ł$ ieden drugiemu odwabiaz czeliadnika albo ucznia

rzędziak, por. rzędny - 'najęty, płatny', ReczekPSdp. 435: Item ktoryby brat miał dwu czeliadniku tedy trzeczego niema przymowacz a na rzędziaka pod winną dwana cczie grofzy 
W tekstach zabytków pyzdrskich używa się wyłącznie wyrazu wielgi spośród tego typu przymiotników jakościowych (brak wieliki, wielki): schaczki Roczne wielgie; pieczęc3 nafza wielga mieifka; aby zaden zbraczi przerzzeczonych nie 3 miał wyprawiacz skor wielgich itd. Dziś przymiotnik wielgi jest postacią gwarową. Przykłady jego użycia: wielgo powódź; wielgo choroba (padaczka); wicher wielgi lecioł trzy dni, pozrywoł dachy, słuma poszła w świat, niedola.

Używa się też w tekstach pyzdrskich wyrazu wilija w różnych formach fleksyjnych:

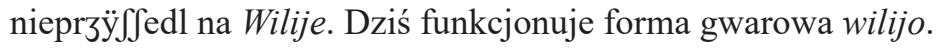

W tekstach zabytków pyzdrskich funkcjonują formy określenia inszy: aby zaden zinfszÿch miafth; winfse dnÿ. Dziś są to określenia potoczne.

We wszystkich zabytkach występuje spójnik podrzędny $i \dot{z}$ (brak eże). Oto zapisy tego spójnika w poszczególnych zabytkach: $\ddot{y} \sqrt{3}, \ddot{y} r z, \ddot{y} s z, \ddot{y} z b y(\mathrm{Nr} 1) ; i \sqrt{3}, y \sqrt{3}, \dot{y} z b y(\mathrm{Nr}$ 2); isz, iszby (Nr 3). Z zabytków Nr 1 i Nr 4 wynotowałem yszbych, a z zabytku Nr 3 azby. Spójnik jeżeli, rozpoczynający zdanie warunkowe, ma w zabytkach $\mathrm{Nr} 2$ i $\mathrm{Nr} 4$ postać rzeli. Z zabytku Nr 4 wynotowałem Ilifch: powinien zaras vkazac od vrodzenia ÿ vezenia.

Antroponimia (zob. Rymut, 2005)

$\mathrm{Nr} 1$

Jedrzeÿ Slawinfkj Burmiftrz

Sławiński - od n. m. Sławno, Rymut II 445

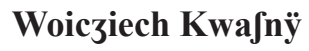

Kwaśny - od kwaśny, Rymut I 502

Grzegorz Grudzienskj

Grudzieński - od n. m. typu Grodno, Rymut I 261

Woiczech Krawiecz

Krawiec - od krawiec

Pawel Marujzka

Maruszka - por. stpol. n. os. Maruszka = Magorzata, Malec, 1995: 85

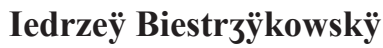

Biestrzykowski - od n. m. Biestrzyków, Rymut I 37

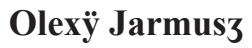

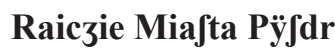 \\ rajcy miasta Pyzdr \\ Slawni mezowie \\ Sławni mężowie
}

Jarmusz - od jarmuż, daw. też od jarmusz, 'jarzyna, rodzaj kapusty', Rymut I 338

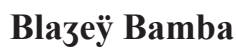

Bąba od gw. bąba 'bąbel, pęcherz', Rymut I 25 


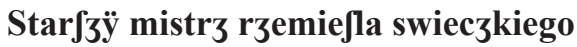 \\ starszy mistrz rzemiosła szewskiego}

\section{Stanislaw Chudzina}

Chudzina - por. chudy

\section{Sijmon Latha}

Łata - por. łata

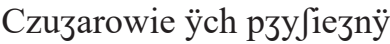

$\mathrm{Nr} 2$

Wszystkie nazwiska te same, niewielkie tylko zmiany morfologiczne. Przy jednym nazwisku dodano suf. -ic: Bambic (Bąbic).

Bambic (Bąbic)

Bąbic ‘syn Bąby', suf. -ic

\section{$\mathrm{Nr} 3$}

\section{Wladislaw Grzymislawski Bormistrz}

\section{Szlachetni y Sławni}

Grzymisławski, por. stpol. n. os. Grzymisław - zob.: psł. * grimati 'grzmieć', Cieślikowa i in., 2000: 86. O staropolskich dwuczłonowych nazwach osobowych zob. Malec, 1971.

\section{Alexi Dwożan}

\section{Raice Miasta Pysdr}

Rajcy Miasta Pyzdr

Dwożan - por. gw. dworzan 'dworzanin', Rymut I 161

\section{Woiciech Oldak}

Oldak - od niem. alt, dniem. Old 'stary', Rymut I 4

\section{Maciei Żeśkow}

Żeśkow - od rzesza 'tłum, gromada', Rymut II 383

\section{Jan Szaiek}

Szajek - por. w dawnej Polsce saja, szaja 'tkanina jedwabna', por. niem. n. os. na Schei-, Rymut II 389

\section{Raphal Wcisło}

Wcisło - od wciskać, wcisnąc 'wtoczyć, wepchnąć', Rymut II 663

\section{Pawel Luman}

\section{Sławni mężowie}

bracia tegosz Cechu Kramarskiego

Luman - od niem. n. os. Lumm, ta od im. na Liut - lub od czes. lumm 'miękki, kruchy, wiotki', Rymut II 27-28 
Michal Zlotnik Starszy bractwa kramarskiego

Złotnik - por. złotnik

\section{Pan Gieln}

Gieln - zob. gieln, Rymut I 232, zob. gleń - od stpol. gleń 'kawałek chleba', Rymut I 238.

\section{Jan Szaiek}

Szajek - zob. wyżej.

\section{$\mathrm{Nr} 4$}

Nazwiska pokrywają się z nazwiskami z tekstu $\mathrm{Nr} 1$.

\section{Uwagi podsumowujące w kontekście innych uwag odnoszących się do języka regio- nalnego Wielkopolski XVI wieku}

I. Podstawą periodyzacji dziejów języka jest ustalenie chronologicznych ram, w których umieszczamy zjawiska charakteryzujące się swoistością form i zasadniczymi tendencjami rozwojowymi. Omawiane w niniejszej pracy zabytki pochodzą z drugiej połowy XVI wieku. Był to okres średniopolski w rozwoju języka polskiego. Zaszły w tym czasie ważne dla kształtowania się języka ogólnego zmiany systemowe. Następowało wówczas obumieranie staropolskiego systemu fonologicznego oraz wielu archaicznych form fleksyjnych (Klemensiewicz, 1985 II: 216). Wymieniam tu kilka najistotniejszych zmian fonetycznych i fleksyjnych, jakie zaszły w omawianym okresie (za: Walczak, 1995: 121):

\section{Zmiany fonetyczne}

1. Zanik samogłosek pochylonych (funkcjonowały w omawianym okresie jako konsekwencja zaniku iloczasu na przełomie wieków XV i XVI).

2. Konsekwencją zaniku iloczasu było też uformowanie się dwu samogłosek nosowych: $e, Q$.

3. Przejście $i r, i r z \mathrm{w}$ er, erz (ir, irz $\rightarrow e r, e r z)$ (zakończenie procesu).

4. Przejście $i l, y l, i t, y t \mathrm{w} e l, e t(i l, y l, i t, y t \rightarrow e l, e t)$.

5. Stwardnienie miękkich spółgłosek wargowych w wygłosie (na końcu wyrazu).

\section{Zmiany fleksyjne}

1. Ukształtowanie się rodzaju męskoosobowego w liczbie mnogiej.

2. Ustalenie się w celowniku, narzędniku i miejscowniku liczby mnogiej wspólnych końcówek dla rzeczowników trzech rodzajów.

3. Zanik liczby podwójnej.

Niżej przedstawiam kilka wniosków nasuwających się z zestawienia cech językowych zabytków pyzdrskich z drugiej połowy XVI wieku z cechami językowymi (wielkopolskimi), jakie zawiera Wykład Argiglobyna (połowa XVI wieku). Właściwości językowe Wykładu Argiglobyna zaprezentowali W.R. Rzepka i B. Walczak (1991: 167-184) w „Slavii Occidentalis". Autorzy artykułu konfrontują materiał Argiglobyna z materiałem ksiąg radzieckich, wójtowskich i gromadzkich Poznania oraz z materiałem Zołtarza Wróbla. Przytaczam tu następującą uwagę T. Brajerskiego (1995: 86): ,Jeronim z Poznania, kopista Wróblowego Zołtarza, na pewno mazurzył. [...] Pisarz zdradza dążenia poprawnościowe 
właściwe Polakom mazurzącym [...]. Powstaje w związku z powyższym problem lokalizacji Jeronima z Poznania, trudno bowiem przypuszczać, że Poznań mazurzył. Przepisywacz musiał przebywać na terenie mazurzącym, zanim się zaczął pisać «z Poznania»”.

Ważniejsze wnioski to:

1. W zabytkach pyzdrskich występuje bezwyjątkowa wymowa rozłożona nosówki przedniej e. Podobnie w cytowanym artykule stwierdza się bezsporną rozszczepioną wymowę Argiglobyna samogłoski ę (w odpowiedniej pozycji).

2. Są podstawy do stwierdzenia, że samogłoska tylna nosowa $Q$ (o nosowe) wymawiana była przez autorów tekstów pyzdrskich asynchronicznie (w sposób rozłożony) w pozycjach:

a) przed spółgłoską wargową zwarto-wybuchową - Bamba, Bambic (Bąba, Bąbic);

b) w wygłosie - sam (są); sam (są) nalezeli, nas są//sąm pro/sieli;

c) być może także przed innymi spółgłoskami zwartymi: przyanć//porzandku.

W.R. Rzepka i B. Walczak nie znajdują podstaw rozstrzygających kwestii, czy autor rękopisu Argiglobyna wymawiał wygłosowe $Q$ ( $o$ nosowe) jak om.

3. Nie można też - według Rzepki i Walczaka - rozstrzygnąć, czy autor rękopisu Argiglobyna wymawiał w wygłosie samogłoskę przednią (ę nosową) odnosowioną. Nie wiadomo także, czy w wymowie redaktorów przywilejów pyzdrskich wygłosowe $e$ traciło nosowość.

4. W staropolszczyźnie znana była oboczność samogłosek $o$ :e uwarunkowana fonetycznie, a odziedziczona z prasłowiańszczyzny - o występowało po spółgłosce twardej, a $e$ po spółgłosce miękkiej. Później trwa proces wyrównawczy pod wpływem formacji z $o$. W zabytkach pyzdrskich występują jeszcze równolegle: formacje z dawnym - 'ew i z nowszym -'ow: córke mistrzewska, syn mistrzewski i synowie mistrzowscy, wiefniaczowi. Autorzy artykułu o języku rękopisu Argiglobyna wykazali, że w pewnych kategoriach gramatycznych ,ew ustępuje przed ,ow.

5. U Argiglobyna, podobnie jak w innych zabytkach wielkopolskich, przegłos jest przeprowadzony konsekwentnie, jak stwierdzają autorzy cytowanego artykułu. W zabytkach pyzdrskich obok form przegłoszonych występują formy nieprzegłoszone: rzemieflo, rzemiefla, w rzemieflie, rzemieszła//rzemiofła. W zabytku Nr 4 są tylko formy nieprzegłoszone. Pod tym względem zmiany językowe zauważone w zabytkach pyzdrskich następują zdecydowanie wolniej.

6. W zabytkach pyzdrskich występuje wielokrotnie forma wielgi. Należy uznać ją za formę gwarową - na tle form wielki, wieliki występujących w innych szesnastowiecznych tekstach. W rękopisie Argiglobyna formy wielgi brak zupełnie - zauważają autorzy artykułu. Dziś forma wielgi znana jest gwarom wschodniej Wielkopolski.

7. Język pyzdrskich zabytków jest jeszcze pod innym względem bardzo konserwatywny w zestawieniu z językiem rękopisu Argiglobyna. Formy dualne (imienne) u Argiglobyna trafiają się wyjątkowo. Zabytki pyzdrskie mają ich wiele.

8. W przywoływanych przez Rzepkę i Walczaka tekstach Ksiąg poznańskich, Żołtarza Wróbla, także w rękopisie Argiglobyna natrafić można na wyrazy z antycypacją spółgłosek palatalnych. W tekstach zabytków pyzdrskich też są takie formy, na przykład na przedmieifscziu. 
9. Zbliżone są zestawiane teksty (rękopis Argiglobyna i teksty pyzdrskie) pod względem powszechności występowania samogłosek pochylonych - jako istotnej cechy językowej Wielkopolski.

10. Zbieżność występujących cech w zestawianych tekstach (rękopis Argiglobyna i teksty pyzdrskie) może dotyczyć jeszcze między innymi:

a) uproszczeń grup spółgłoskowych - charakterystycznych dla dzisiejszych gwar wielkopolskich (u Argiglobyna są formy pow ÿfzala, powyfzil, nawiffy itp. - a tek-

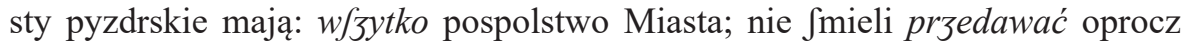
iarmarku; niema przymowacz na rzędziaka; przijffedszÿ);

b) identycznej w zestawionych tekstach formy kozdy;

c) formacji z przedrostkiem na-;

d) konserwatyzmu w zakresie partykuły trybu warunkowego w liczbie pojedynczej -bych (w tekście zabytku pyzdrskiego $\mathrm{Nr} 1$ pojawia się jeden raz spójnik yszbych).

W zestawieniu zawartości językowych zabytków pyzdrskich i rękopisu Argiglobyna uwidaczniają się różnice w tendencjach rozwojowych, unifikacyjnych - kształtujących polski język literacki. Są to różnice terytorialne, dotyczące wewnątrzjęzykowej wielkopolskiej odmiany regionalnej. Mimo iż rękopis Argiglobyna pochodzi z pierwszej połowy, a teksty pyzdrskie z drugiej połowy wieku, rękopis Argiglobyna jest już w stosunku do tekstów pyzdrskich na wyższym etapie dokonujących się wówczas językowych zmian. Na przykład brak przejścia $i l \rightarrow$ el tłumaczy się oddziaływaniem normy ogólnopolskiej (por. Rzepka, Walczak, 1991: 183, przypis 17). W tekstach pyzdrskich występuje przejście $i l \rightarrow e l$. Pyzdry to głęboka prowincja w stosunku do ośrodka kulturalnego Wielkopolski, jakim był Poznań. Zmiany kulturalne, w tym językowe, musiały siłą rzeczy przebiegać z różnymi terytorialnie ograniczeniami. Na tym przede wszystkim polega wartość poznawcza tekstów pyzdrskich, że zastygły w nich niektóre dawne formy językowe (patrz formy nieprzegłoszone, formy dualne, stare postaci wyrazowe tuta, tuteczny i inne).

Trudno doszukiwać się szerszych potwierdzeń w tekstach pyzdrskich zjawisk zacierania się odrębności regionalnej języka literackiego w Wielkopolsce (także tendencji normalizacyjnych), o których pisze między innymi W.R. Rzepka (1993: 275-282) w swym artykule, gdyż słownictwo tekstów pyzdrskich ogranicza się do przedstawienia (opisu) norm prawnych oraz formuł pełnionych funkcji, nakazów i sankcji obejmujących poszczególne bractwa rzemieślnicze.

Mimo szczupłości materiału przeprowadzona przeze mnie analiza historyczno-językoznawcza tekstów pyzdrskich może przyczynić się do uzupełnienia wiedzy o języku Wielkopolan drugiej połowy XVI wieku. Może to na przykład dotyczyć zróżnicowania terytorialnego w obrębie tego samego regionu. Język dalekiej prowincji zachowuje szereg właściwości z odległych epok i kultywuje je przez długi czas, a niektóre z nich mają kontynuacje w obecnych gwarach. Mogą to być odstępstwa od przegłosu (tak licznie występujące w tekstach pyzdrskich), zachowane do dziś w gwarach w różnym zakresie i z różnym nasileniem. Może to być funkcjonujące w Wielkopolsce północno-wschodniej dialektalne zjawisko podwyższenia do granic możliwości artykulacji kontynuantów szesnastowiecznych samogłosek pochylonych (tu prezentuję dość liczną grupę przykładów): 
un miszko na górański ulicy (on mieszka na Gorańskiej ulicy); nie być taki świnty (nie bądź taki święty); kwosek dobry ino mało; inzioro wyschło (jezioro wyschło); Rumciu Ksawery bepsztyk (Romciu Ksawery befszyk); leciot pies przez łowies, łogunym wywijoł, pewnie jest kawalir, szczynśliwo bestyjo (leciał pies przez owies, ogonem wywijał, pewnie jest kawaler, szczęśliwa bestyja).

\section{Zakończenie}

W niniejszej pracy starałem się ukazać te właściwości językowe, które udało mi się wydobyć z zabytków rękopiśmiennych w Pyzdrach. Obraz przedstawionych zjawisk nie jest może pełny ze względu na trudności w odczytaniu niektórych partii tekstu (plamy, zatarcia).

Najistotniejsze spośród przedstawionych zjawisk są właściwości językowe wielkopolskie. Na tym głównie polega wartość odkrytych zabytków. Poza tym ich analiza pozwala nam dostrzec, jak przebiegał rozwój pewnych procesów. W pracy uwypukliłem między innymi nasilenie się procesu rozłożenia wymowy samogłosek nosowych, sporadyczny charakter przejścia $i l$ w el $(i l \rightarrow e l)$, występowanie w szeregu wypadkach właściwości językowych konserwatywnych (zachowanie liczby podwójnej; odmiana rzeczownika zbiorowego bracia; nieuproszczone grupy spółgłoskowe: *dbs *tbs; zachowanie miękkości $l$ ', $l j$ - także w położeniu innym niż przed $i$; głęboki archaizm w postaci wyrazowej szwieckiego (szewskiego) jako refleksu dawno zakończonego procesu rozwojowego jerów.

Przywileje mieszczańskie były ważnym elementem ustroju wewnętrznego miasta (zagadnienie to możliwie wyczerpująco przedstawiłem w niniejszym artykule). W pracy podkreślałem, że język zabytków jest archaiczny. Mimo ekonomicznego rozwoju w omówionym okresie historii i znakomitego bogactwa mieszczan aspekty rzeczywistości społeczno-kulturowej (pisarze zabytków byli członkami społeczeństwa Pyzdr) miały charakter regionalny. Prezentowany w pracy statut cechu szewskiego jest charakterystycznym odzwierciedleniem kultury zawodowej, społecznej mieszczan, ich światopoglądu i postaw moralnych. Mocno podkreślany w pracy charakterystyczny zastój rozwoju języka jest pochodną prowincjonalizmu na wszystkich poziomach kultury.

\section{Spis cytowanych publikacji}

Bargieł M. (1969), Cechy dialektalne polskich zabytków rękopiśmiennych pierwszej połowy XVI wieku, Wrocław-Warszawa-Kraków.

Brajerski T. (1995), O języku polskim dawnym i dzisiejszym, Lublin.

Chojnacki J. (1994), O zabytkach rękopiśmiennych języka polskiego z Pyzdr z końca XVI w. Sprawozdania Wydziału Filologiczno-Filozoficznego, cz. 2, Poznań.

Cieślikowa A., Szymowa J., Rymut K. (oprac.) (2000), Słownik etymologiczno-motywacyjny staropolskich nazw osobowych. Część 1. Odapelatywne nazwy osobowe, Kraków.

Czerniak M. (2007), Wstęp, [w:] J. Łojko, Civitas Pyzdry. Dzieje miasta do roku 1793, Pyzdry. 
Czerniak R.M. (oprac.) (2007), Civitas Pyzdry, 750 lat lokacji miasta, Pyzdry.

Dejna K. (1973), Dialekty polskie, Wrocław-Warszawa-Kraków-Gdańsk.

Doroszewski W. (red.) (1963), Słownik języka polskiego, t. V, Warszawa.

Doroszewski W. (red.) (1964), Słownik języka polskiego, t. III, Warszawa.

Góralski Z. (1983), Urzędy i godności w dawnej Polsce, Warszawa.

Ihnatowicz I., Mączak A., Zientara B., Żarnowski J. (1988, 1996, 1999, 2005), Społeczeństwo polskie od $X$ do $X X$ wieku, Warszawa.

Karłowicz J., Kryński A., Niedźwiedzki W. (1902), Słownik języka polskiego, t. II, Warszawa.

Karłowicz J., Kryński A., Niedźwiedzki W. (1908), Słownik języka polskiego, t. IV, Warszawa.

Klemensiewicz Z. (1985), Historia języka polskiego, t. I-II, Warszawa.

Klemensiewicz Z., Lehr-Spławiński T., Urbańczyk S. (1956), Gramatyka historyczna języka polskiego, Warszawa.

Konopczyński W. (1936), Dzieje Polski nowożytnej, Warszawa-Kraków-Lódź-Poznań-WilnoZakopane.

Kuraszkiewicz W. (1951), Oboczność -’ev-//-’ov- w dawnej polszczyźnie $i w$ dzisiejszych gwarach, Wrocław.

Kuraszkiewicz W. (1986a), Z historii polskich samogłosek nosowych, [w:] W. Kuraszkiewicz, Polski język literacki. Studia nad historia i struktura, Warszawa-Poznań.

Kuraszkiewicz W. (1986b), Ze studiów nad polskimi samogłoskami nosowymi (Rezonans nosowy), [w:] W. Kuraszkiewicz, Polski język literacki. Studia nad historia i struktura, Warszawa-Poznań.

Kuraszkiewicz W. (1986c), Najdawniejszy przejaw zbieżności głosek rz $i$ ż u pisarza pyzdrskiego z lat 1410-1418, [w:] W. Kuraszkiewicz, Polski język literacki. Studia nad historia i struktura, Warszawa-Poznań.

Lange O. (1925), Lokacje miast Wielkopolski właściwej na prawie niemieckim w wiekach średnich (z mapa), Lwów.

Łojko J. (2007), Civitas Pyzdry. Dzieje miasta do roku 1793, Pyzdry.

Malec M. (1971), Budowa morfologiczna staropolskich imion osobowych, Wrocław-WarszawaKraków.

Malec M. (oprac.) (1995), Stownik etymologiczno-motywacyjny staropolskich nazw osobowych. Część 2. Nazwy osobowe pochodzenia chrześcijańskiego, Kraków.

Moszyński L. (2006), Wstęp do filologii stowiańskiej, Warszawa.

Reczek S. (1968), Podręczny słownik dawnej polszczyzny, Wrocław-Warszawa-Kraków.

Rospond S. (1973), Gramatyka historyczna języka polskiego, Warszawa.

Rymut K. (1999-2001), Nazwiska Polaków. Słownik historyczno-etymologiczny, t. I-II, Kraków.

Rymut K. (2005), Nazwiska, [w:] E. Rzetelska-Feleszko (red.), Polskie nazwy własne. Encyklopedia, Kraków. 
Rzepka W.R. (1985), Demorfologizacja rodzaju w liczbie mnogiej rzeczowników w polszczyźnie XVI-XVII wieku, Poznań.

Rzepka W.R. (1993), Odrębność regionalna polszczyzny literackiej w Wielkopolsce $w$ XVIXVII w., [w:] M. Basaj, Z. Zagórski (red.), Numera lingwistica Ladislao Kuraszkiewicz dedicata, Wrocław-Warszawa-Kraków.

Rzepka W.R., Walczak B. (1991), Właściwości językowe wielkopolskiego rękopisu Jerzego Argiglobyna (Poznańczyka) z połowy XVI w., „Slavia Occidentalis”, t. 46/47.

Sławski F. (1958-1965), Słownik etymologiczny języka polskiego, t. II, Kraków.

Sławski F. (1966-1969), Słownik etymologiczny języka polskiego, t. III, Kraków.

Sobierajski Z. (1952), Gwary kujawskie, Poznań.

Sobierajski Z. (1960), Z przeszłości gwar pótnocnej Wielkopolski XVII-XVIII w., „Slavia Occidentalis", t. 20, z. 1.

Śmiech W. (1953), Rozwój historyczny polskich grup spółgłoskowych, Łódź.

Tokarski J. (red. nauk.) (1974), Słownik wyrazów obcych, Warszawa.

Tomaszewski A. (1938), O zbieraniu materiału gwarowego z ksiag ławniczych, „Biuletyn Towarzystwa Językoznawczego", z. VII.

Urbańczyk S., Klemensiewicz Z., Safarewicz J., Kuraszkiewicz W., Ostrowska E., Taszycki W. (red.) (1974), Stownik staropolski, t. VII, z. 3(43), Wrocław-Warszawa-Kraków-Gdańsk.

Urbańczyk S., Klemensiewicz Z., Safarewicz J., Kuraszkiewicz W., Taszycki W. (red.) (1968), Słownik staropolski, t. V, z. 7(31), Wrocław-Warszawa-Kraków.

Urbańczyk S., Klemensiewicz Z., Safarewicz J., Kuraszkiewicz W., Ostrowska E., Taszycki W. (red.) (1969), Stownik staropolski, t. V, z. 8(32), Wrocław-Warszawa-Kraków.

Urbańczyk S., Klemensiewicz Z., Safarewicz J., Kuraszkiewicz W., Taszycki W. (red.) (1960-1962), Stownik staropolski, t. III, z. 6(19), Wrocław-Warszawa-Kraków.

Urbańczyk S., Klemensiewicz Z., Safarewicz J., Kuraszkiewicz W., Taszycki W. (red.) (1964), Stownik staropolski, z. 4(23), Wrocław-Warszawa-Kraków.

Urbańczyk S., Safarewicz J., Kuraszkiewicz W. (red.) (1991), Słownik staropolski, t. X, z. 4(64), Kraków.

Urbańczyk S., Safarewicz J., Kuraszkiewicz W., Ostrowska E., Taszycki W. (red.) (1973), Stownik staropolski, t. VI, z. 7(40), Wrocław-Warszawa-Kraków-Gdańsk.

Walczak B. (1995), Zarys dziejów języka polskiego, Poznań.

Wędzki A. (2007), Przechadzki po Wielkopolsce, Poznań.

Wiśniewska H. (1975), Polszczyzna przemyska wieków XVII-XVIII, Wrocław-WarszawaKraków-Gdańsk. 


\section{Abstract \\ Handwritten monuments from Pyzdry from the second half of the XVI century. Historical conditions. Linguistic properties in the context of development and unification tendencies of the national language}

In the Regional Museum in Pyzdry (a town on the Warta River) there are sixteenth-century handwritten language monuments (of the Polish language). The monuments contain the content of town privileges from Pyzdry (second half of the $16^{\text {th }}$ century). The article contains a short description of the privileges concerning the royal city of Pyzdry. The historical monuments were analyzed in the context of documented linguistic phenomena in Wielkopolska (with particular emphasis on regional features).

Keywords: bourgeois privileges, shaping of the Polish language, regional linguistic archaisms, continuations of some $16^{\text {th }}$-century regionalisms in contemporary dialects 